NBER WORKING PAPER SERIES

\title{
THE REAL EFFECTS OF LIQUIDITY DURING THE FINANCIAL CRISIS: EVIDENCE FROM AUTOMOBILES
}

\author{
Efraim Benmelech \\ Ralf R. Meisenzahl \\ Rodney Ramcharan \\ Working Paper 22148 \\ http://www.nber.org/papers/w22148
NATIONAL BUREAU OF ECONOMIC RESEARCH 1050 Massachusetts Avenue
Cambridge, MA 02138 April 2016

We thank Bo Becker, Gadi Barlevi, Gabriel Chowdorow-Reich, Dan Covitz, Diana Hancock, Arvind Krishnamurthy, Gregor Matvos, Jonathan Parker, Wayne Passmore, Karen Pence, Phillip Schnabl, Andrei Shleifer (the editor), Jeremy Stein, Philip Strahan, Amir Sufi, three anonymous referees, and seminar participants at the 2015 AEA Meetings, Basel Research Task Force, Berkeley (Haas), CSEF-IGIER Symposium in Economics and Institutions (Capri), Cornell, Dutch National Bank, Emory University, Entrepreneurship and Finance Conference in memory of Ola Bengtsson (Lund University), Federal Reserve Board, Federal Reserve Bank of Chicago, Federal Reserve Day Ahead Conference, Georgetown University, Georgia State University, Hong Kong University, Indiana University (Kelley School of Business), NBER Summer Institute, NBER Corporate Finance Meeting, NBER Monetary Economics Meeting, Northwestern University (Kellogg), Pennsylvania State University (Smeal), Singapore Management University, Stanford University, Tsinghua University, Tulane University, University of Munich, and University of Illinois at Urbana-Champaign for very helpful comments. Della Cummings, Sam Houskeeper, Jeremy Oldfather, and Jeremy Trubnick provided excellent research assistance. Benmelech is grateful for financial support from the National Science Foundation under CAREER award SES-0847392. The views expressed here are those of the authors and do not necessarily reflect the views of the Board of Governors, the staff of the Federal Reserve System, or the National Bureau of Economic Research.

NBER working papers are circulated for discussion and comment purposes. They have not been peer-reviewed or been subject to the review by the NBER Board of Directors that accompanies official NBER publications.

(C) 2016 by Efraim Benmelech, Ralf R. Meisenzahl, and Rodney Ramcharan. All rights reserved. Short sections of text, not to exceed two paragraphs, may be quoted without explicit permission provided that full credit, including $(\odot)$ notice, is given to the source. 
The Real Effects of Liquidity During the Financial Crisis: Evidence from Automobiles Efraim Benmelech, Ralf R. Meisenzahl, and Rodney Ramcharan

NBER Working Paper No. 22148

April 2016

JEL No. G01,G23,L62

\begin{abstract}
$\underline{\text { ABSTRACT }}$
Illiquidity in short-term credit markets during the financial crisis might have severely curtailed the supply of non-bank consumer credit. Using a new data set linking every car sold in the United States to the credit supplier involved in each transaction, we find that the collapse of the assetbacked commercial paper market reduced the financing capacity of such non-bank lenders as captive leasing companies in the automobile industry. As a result, car sales in counties that traditionally depended on non-bank lenders declined sharply. Although other lenders increased their supply of credit, the net aggregate effect of illiquidity on car sales is large and negative. We conclude that the decline in auto sales during the financial crisis was caused in part by a credit supply shock driven by the illiquidity of the most important providers of consumer finance in the auto loan market. These results also imply that interventions aimed at arresting illiquidity in short-term credit markets might have helped to contain the real effects of the crisis.
\end{abstract}

Efraim Benmelech

Kellogg School of Management

Northwestern University

2001 Sheridan Road

Evanston, IL 60208

and NBER

e-benmelech@kellogg.northwestern.edu

Ralf R. Meisenzahl

Board of Governors of the Federal Reserve System

20th Street and Constitution Ave NW - MS 145

Washington, DC 20551

Ralf.R.Meisenzahl@frb.gov
Rodney Ramcharan

University of Southern California

Rodney.ramcharan@gmail.com 


\section{INTRODUCTION}

Financial crises can have large adverse effects on real economic activity. Illiquidity in one corner of the financial system and large realized balance-sheet losses in the financial sector can lessen the aggregate credit supply and spur economic decline. ${ }^{1}$ Consistent with these theoretical predictions, there is growing evidence from the 2007-2009 financial crisis that the balance-sheet losses incurred by traditional financial institutions-banks and credit unionsmight have led to a fundamental post-crisis disruption in credit intermediation, contributing to the recession and the subsequent slow economic recovery (Chodorow-Reich 2014; Ramcharan van den Heuvel and Verani forthcoming). ${ }^{2}$

However, non-bank financial institutions-such as finance and leasing companies-are historically important sources of credit, especially for purchases of such consumer durable goods as automobiles and appliances (Ludvigson 1998). Before the crisis, for example, non-bank lenders financed more than half of all new cars bought in the United States (Table A.I). Unlike most traditional banks, non-bank financial institutions have connections to the shadow banking system, relying for funding primarily on short-term markets, such as the asset-backed commercial paper (ABCP) market.

We investigate how runs in the $\mathrm{ABCP}$ market and the loss of financing capacity at nonbank institutions, such as the captive leasing arms of car manufacturers, might have curtailed the supply of auto credit, led to the collapse in car sales, and exacerbated the financial difficulties of companies such as General Motors (GM) and Chrysler that were already verging on bankruptcy. Between 2007 and 2008, short-term funding markets in the United States dried up as money market funds (MMFs) and other traditional buyers of short-term debt fled these markets (Covitz, Liang, and Suarez 2013). Although the initial decline in 2007 was driven mainly by ABCP backed by mortgage-backed securities, the decline following the Lehman Brothers bankruptcy affected all $\mathrm{ABCP}$ issuers.

By early 2009, growing illiquidity in the ABCP market—a key source of short-term credit in the United States-made it difficult for many non-bank intermediaries to roll over debt or secure new funding (Campbell et al. 2011). This illiquidity coincided with the collapse of

\footnotetext{
${ }^{1}$ See, e.g., Allen and Gale 2000; Diamond and Rajan 2005, 2011; and Shleifer and Vishny 2010.

${ }^{2}$ The crisis may have also disrupted intermediation even at such nontraditional lenders as Internet banks (Ramcharan and Crowe 2012).
} 
several large non-bank lenders, chief among them the General Motors Acceptance Corporation (GMAC), the financing arm of GM and one of the world's largest providers of auto financing. At the same time, automobile sales fell dramatically in 2008 and 2009, and GM and Chrysler eventually filed for Chapter 11 bankruptcy protection.

To uncover the economic consequences of these disruptions in short-term funding markets, we use a proprietary micro-level data set from R. L. Polk \& Company (Polk) of all new car sales in the United States. Our data set matches every new car sale to its financing source (for example, auto loan or lease) and identifies the financial institution involved in the sale. The data, reported quarterly starting in 2002, also identify each vehicle's make and model, along with county of registration. This micro-level detailed information and its spatial nature enable us to develop an empirical identification strategy to identify how the loss of financing capacity in the shadow banking system might have affected U.S. car sales.

Our identification strategy hinges on the notion that by the end of 2008, liquidity runs in the ABCP market and dislocations in other short-term funding markets might have curtailed the financing capacity of non-bank institutions, notably the captive financing arms of automakers. We show cross-sectionally that in counties in which buyers are historically more dependent on non-bank lenders for auto credit, sales of cars fell even more sharply in 2009. In particular, a one standard deviation increase in non-bank dependence is associated with a 1 percentage point or 0.08 standard deviation decline in the growth in new car transactions over the 2008-2009 period. This point estimate implies that even with the unprecedented interventions aimed at unfreezing short-term funding markets in 2008 and 2009, as well as the bailout of the U.S. automakers and their financing arms, the liquidity shock to non-bank financing capacity might explain about 31 percent of the drop in car sales in 2009 relative to 2008.

Non-bank lenders tend to serve lower-credit-quality borrowers-the very borrowers identified as most affected by the Great Recession. There is compelling evidence, for example, that these borrowers suffered significantly from the collapse in house prices, reducing their demand for automobiles and other durable goods (Mian and Sufi 2014). These borrowers are also more likely to have faced a reduction in their credit card limits. And rather than reflecting the effects of diminished captive financing caused by illiquidity in short-term funding markets, the results reported here could reflect a more general contraction in credit to riskier borrowers. 
To address this challenge to causal inference, we show that our county-level results are robust to the inclusion of the most common proxies for household demand-house prices, household leverage, and household net worth—as well as to measures of unemployment (Mian and Sufi 2014a). We also find evidence of substitution: sales financed by noncaptive lendersthose financial institutions more dependent on traditional deposits for funding - actually rose during this period in counties where borrowers had a higher dependency on non-bank credit. The evidence on substitution from non-bank to bank financing suggests that our results are unlikely to be driven by latent demand factors; rather, they reflect a credit supply shock.

The rich data, especially the make-segment information, allow us to address other concerns about county-level omitted variables. Within the same make, manufacturers use different models to appeal to diverse consumers at varying price points. General Motors, for example, markets Chevrolets to nonluxury buyers, whereas it promotes Cadillacs to wealthier consumers. And the effects of the Great Recession on likely buyers of Chevrolets were probably very different than on potential buyers of Cadillacs, even for those living in the same county. We can thus use county-segment fixed effects to nonparametrically control for differences in demand within a county across different model segments. Our results remain unchanged.

Whereas the Polk data set is rich in its coverage of information regarding automobiles, it contains no information on borrower characteristics. We supplement the data from Polk with a large micro-level panel data set from Equifax of about three million individuals. The Equifax data include the dynamic FICO score of each borrower, along with age, automotive credit, mortgage, and other credit usage measures. For automotive debt, the data set also identifies whether credit was obtained from a non-bank or bank lender. Although Equifax does not provide as rich a set of information about the car purchase as Polk, it has a wealth of borrower characteristics that directly address concerns about borrower credit quality, credit access, and latent demand among users of non-bank credit relative to other sources of automotive credit. Combining information from Polk and Equifax enables us to alleviate concerns pertaining to omitted variables at both the borrower and the car level.

Using the Equifax data and controlling for FICO scores, homeownership status, and other observables, we find significant evidence that for borrowers living in counties more traditionally dependent on non-bank financing, the probability of obtaining non-bank credit fell sharply over the 2008-2009 period, becoming zero in late 2009. Falsification tests reveal no similar pattern 
for either mortgage or revolving lines of credit. Further, we find that access to non-bank automotive credit declined sharply toward the end of 2008 and again in the second half of 2009 even among borrowers with high FICO scores.

Taken together, these results imply that funding disruptions in short-term credit markets during the financial crisis significantly diminished car sales. This evidence of a credit supply shock adds to our understanding of financial crises more broadly and complements those papers that emphasize alternative mechanisms, such as the role of debt, deleveraging, and regulation, that might shape post-credit boom economies (see Mian and Sufi 2010, 2014a; Mian, Rao, and Sufi 2013; and Rajan and Ramcharan 2015, 2016, forthcoming). We argue that a credit supply channel during the crisis was especially important in the new car auto market because more than 80 percent of new cars in the United States are financed through leases and auto loans from nonbank and bank lenders; under 20 percent are bought in all-cash transactions. Our evidence also tentatively suggests that the Treasury and Federal Reserve programs aimed at arresting illiquidity in credit markets might have helped to contain the real effects of the crisis (Goolsbee and Krueger 2015).

This paper also adds to the broader literature on the effects of financial markets and bank lending on real economic outcomes. ${ }^{3}$ But whereas previous studies of the financial crisis document the importance of short-term funding for banks' liquidity and lending, less is known about the consequences of the collapse of short-term funding markets. Also less well understood is the importance of leasing companies and non-bank institutions in the provision of credit in auto markets and how these institutions might be connected to nontraditional sources of financing. We fill this void by documenting that the collapse of short-term funding reduced auto lending by financial institutions, which in turn resulted in fewer purchases of cars and reduced economic activity. We also provide evidence that, because the ABCP market collapse curtailed the financing capacity of many captive financing companies, illiquidity in the short-term funding markets might have played an important role in limiting the supply of non-bank consumer credit during the crisis. ${ }^{4}$

\footnotetext{
${ }^{3}$ See Khwaja and Mian (2008); Brunnermeier (2009); Gorton (2010); Ivanshina and Scharfstein (2010); Acharya, Schnabl, and Suarez (2011); Cornett et al. (2011); Gorton and Metrick (2012); Acharya and Mora (2013); and Becker and Ivashina (2014).

${ }^{4}$ Kacperczyk and Schnabl (2010) provide a detailed account of the collapse of the commercial paper market during the financial crisis of 2007-2009. Gao and Yun (2013) study the consequences of illiquidity in the commercial paper market for corporate borrowing.
} 
The rest of the paper is organized as follows. Section II describes the institutional background of captive leasing and institutions' reliance on ABCP funding. Section III presents the data and the main summary statistics. Section IV describes the construction of our measure of captive dependence. Section V displays the empirical results on the collapse of auto sales using the Polk data. Section VI presents our micro-level analysis using the Equifax data. Section VII concludes.

\section{Automotive Non-Bank CREDIT}

Non-bank financial institutions, especially the captive financing arms of the major automobile manufacturers, have long been important suppliers of automotive credit in the United States. Online Appendix Table A.I shows that in 2005 about half of automotive credit came from non-bank sources of credit. ${ }^{5}$ Among these non-bank purveyors of credit, captives accounted for around 90 percent of non-bank financing in 2008 (Table A.II). The rise of non-bank automotive financing, especially that of captives, arose because the automobile industry's unique combination of high cost, mass appeal, and independent dealership networks required a new form of financing to expand distribution and sales. A further impetus came from the reluctance of many commercial banks to use cars as collateral.

Banks were reluctant to make car loans because cars were a relatively novel and difficultto-value durable good. For example, banks had scant information about a model's depreciation path, especially given that the introduction of new models often led to a sharp drop in the resale value of outgoing models. When banks did make car loans, interest rates often approached the legal maximum. Some bankers even thought it unwise for commercial banks to provide credit for a luxury good out of concern that such credit might discourage the virtue of thrift (Phelps 1952). Last, car sales were highly seasonal, and banks' reluctance to provide automotive financing affected the ability of dealers to finance their inventories (Hyman 2011).

The organizational form of captives was a response to these frictions. Captives such as General Motors Acceptance Corp, founded in 1919, were vertically integrated into the manufacturer and better able to overcome informational frictions surrounding the value of car

\footnotetext{
${ }^{5}$ The prefix A refers to supplementary materials in the Online Appendix.
} 
collateral. ${ }^{7}$ They knew, for example, the model release schedule well ahead of arm's-length lenders. Vertically integrated captives were also less encumbered by moral objections to consumer spending on cars. On the dealer side of the transaction, captives often allowed the dealer to intermediate captive credit and earn additional markups. Captives became important sources of credit or floorplan financing for the dealer - a form of credit collateralized by the dealer's auto inventory. ${ }^{8}$ Captives thus relaxed financial constraints at both the dealership and consumer sides of the sales transaction. ${ }^{9}$

The modern auto credit market is large because most new cars in the United States are bought on credit through either car loans or leasing. At its peak in 2006, auto credit was $\$ 785$ billion, accounting for 32 percent of consumer debt, and assets at GMAC, then the largest of the captive financiers, totaled around $\$ 26$ billion. Captive lessors are also often seen as providing credit to riskier borrowers (Barron, Chong, and Staten 2008; Einav, Jenkins, and Levin 2013). ${ }^{11}$ In 2006, the median FICO score for car buyers obtaining non-bank credit was 640, as opposed to 715 for buyers using bank credit.

Before the financial crisis, securitization gave non-bank suppliers of automotive credit new ways to tap into cheap funding (Calder 1999; Hyman 2011). ${ }^{12}$ In particular, ABCP became

\footnotetext{
${ }^{7}$ Import brands such as Toyota tend to rely more heavily on non-bank captives that are not vertically integrated. For example, existing non-bank lenders, such as World Omni Financial, created a dedicated subsidiary, Southeast Toyota Finance, in 1981, to help Toyota establish a foothold in the American market in key geographic regions. Toyota Motor Credit was established only in 1982 and focuses on markets outside the Southeast (Kaisha 1988).

${ }^{8}$ These points are echoed by William C. Durant in announcing the formation of GMAC in a letter dated March 15, 1919: "The magnitude of the business has presented new problems in financing which the present banking facilities seem not to be elastic enough to overcome. ... This fact leads us to the conclusion that the General Motors Corporation should lend its help to solve these problems. Hence the creation of General Motors Acceptance Corporation; and the function of that Company will be to supplement the local sources of accommodation to such extent as may be necessary to permit the fullest development of our dealers' business" (Sloan 1964, p. 303).

${ }^{9}$ Murfin and Pratt (2015) expand on these ideas within a theoretical model and provide evidence based on equipment leasing.

${ }^{11}$ Charles, Hurst, and Stephens (2010) document that minorities, in particular African Americans, are more likely to receive auto loans from financing companies and to pay, on average, higher interest rates on those loans. One plausible explanation for this pattern is that minorities have, on average, lower credit scores and therefore are more likely to receive financing from captives. For a detailed analysis of subprime auto-lending contracts, see Adams, Einav, and Levin (2009); and Einav, Jenkins, and Levin (2012).

${ }^{12}$ Table A.III in the Online Appendix, based on nonpublic data collected by the Federal Reserve, demonstrates the importance of commercial paper as a source of funding for selected major automobile captives active in the United States. Given the nature of the data, we cannot disclose the identities of the captive lessors in the table and instead label them Captive 1 through Captive 4. As Table A.III shows, commercial paper was a major source of funding for three out of the four captive lessors. Although commercial paper accounted for just 10.2 percent of one lessor's liabilities (Captive 3), the other three captive lessors relied much more heavily on this form of short-term funding, with the share of commercial paper in their liabilities ranging from 45.9 percent (Captive 2) to 75.1 percent (Captive 4).
} 
non-bank lenders' main source of funding, enabling them to turn relatively illiquid auto term loans into liquid assets that could be used to obtain funding for new loans. In this form of securitization, pooled auto loans are placed in a special purpose vehicle (SPV) that is bankruptcy remote from the originating captive lessor. The SPV then issues short-term secured commercial paper $(\mathrm{ABCP})$ to finance loans and market the commercial paper-generally with a duration of no more than three months (see Acharya, Schnabl, and Suarez 2011 for a detailed discussion of ABCP structures).

Money market funds and other institutional investors seeking to invest in liquid and highyield short-term assets are the main buyers of commercial paper. In mid-2007, just before the turbulence in credit markets, MMFs held about 40 percent of outstanding commercial paper in the United States. The bankruptcy of Lehman Brothers on September 15, 2008, and the "breaking of the buck" at Reserve Primary Fund the next day triggered heavy outflows from MMFs, leading the Treasury to announce an unprecedented guarantee program for virtually all MMF shares. The Federal Reserve followed suit by announcing a program to finance purchases of $\mathrm{ABCP}$ — which were highly illiquid at the time - from MMFs. Despite these interventions, flows into MMFs remained highly erratic, and MMFs significantly retrenched their commercial paper holdings. In the three weeks following Lehman's bankruptcy, prime MMFs reduced their holdings of commercial paper by $\$ 202$ billion, a steep decline of 29 percent.

The reduction in commercial paper held by MMFs led to a sharp rise in borrowing costs for issuers of commercial paper. ABCP issuances also fell sharply amid the turmoil in short-term credit markets, and the sharp outflows of assets from MMFs in the third quarter of 2008 precipitated a run on many of these auto-related securitization pools. Figure A.I in the Online Appendix displays the outstanding amount of ABCP issued by SPVs associated with the captive leasing arms of the big three American automakers: GMAC, Chrysler Financial (CF), and Ford Motor Credit (FMC). Although the ABCP market began to weaken in 2007, automakers' issuance of ABCP began to collapse in the third quarter of 2008. Together, the big three captive lessors had about $\$ 40$ billion worth of ABCP outstanding in 2006 before they largely collapsed by the end of $2009 .^{13}$

\footnotetext{
${ }^{13}$ Ford's financing arm, FMC, survived the crisis in part because of its continued access to the Federal Reserve's Commercial Paper Funding Facility (CPFF), which bought ABCP to alleviate liquidity pressures in the funding markets after the Lehman collapse. The Federal Reserve announced the CPFF to provide a liquidity backstop for
} 
Before turning to the data and statistical tests, we provide narrative-based evidence on how the decline in non-bank financing capacity might have affected automobile sales. Although non-bank lenders such as captives are key providers of consumer credit, they are also an important source of credit for auto dealerships. The floorplan financing provided by non-bank lenders enables dealerships to purchase their car inventory. Although it is not easy to obtain dealership-level data on floorplan loans, we have read the financial reports of the largest publicly traded automotive dealerships in the United States to understand the challenges that auto dealerships faced during the Great Recession.

In these reports, these dealerships frequently list a lack of financing for both consumers and dealerships as a first-order reason for the decline in auto sales. Collectively, these reports point to the possibility that the illiquidity of non-bank lenders might have led to a decline in auto sales through a credit supply channel that affected not only consumers but also car dealerships. We collect and reproduce discussions from the Form 10-Ks of the largest publicly traded dealership companies in the United States that pertain to the role of non-bank credit and the automotive industry in general and during the financial crisis and report on them in the Online Appendix.

\section{DATA AND SUMMARY STATISTICS}

For our county-level analysis we use a proprietary data set from R. L. Polk \& Company that records all new car sales in the United States. Beginning in 2002, for each new car purchased in the United States, the data set identifies the vehicle make and model, such as Ford (make) Focus (model) or Toyota (make) Camry (model), and whether the car was purchased by a private consumer (retail purchase), a firm (commercial purchase), or the government. The data set also details the county, year, and quarter of vehicle registration. Because we are interested in identifying the effect of a credit supply shock on household consumption, we focus exclusively on retail purchases. Moreover, for each retail credit transaction starting in the first quarter of

U.S. commercial paper issuers with high short-term credit ratings on October 14, 2008. Before losing access in January 2009, GMAC heavily relied on CPFF, selling a total of $\$ 13.5$ billion in ABCP to the facility. In contrast to GMAC and CF, FMC was able to maintain its short-term credit rating and never lost access to CPFF, from which it had raised almost $\$ 16$ billion by summer 2009 and then began again to raise funds from private investors. 
2008, Polk lists the name of the financial institution and type of financial services provider: bank, credit union, or non-banks such as the automaker's captive financing arm.

Using the Polk data, we replicate the well-known observation that durable goods purchases-in particular automobiles-declined sharply during and after the financial crisis. Figure A.II in the Online Appendix plots the number of automobiles sold annually from 2002 to 2013. Car sales plummeted from a peak of 17 million units in 2006 to 11 million units in 2009 before rebounding slightly in 2010 and 2011. In 2012, auto sales had recovered to around 14 million units sold, and by 2013 sales approached pre-crisis levels. The decline in automobiles sales during the crisis was driven largely by retail auto sales. ${ }^{14}$

Summary statistics of annual county-level retail auto sales are reported in the Online Appendix (Table A.IV). County-level mean sales dropped from 3,866 units in 2007 to 3,168 and 2,563, respectively, in 2008 and 2009, reflecting the dramatic decline in auto sales during the crisis. This pattern of dramatic decline is not driven by outlier counties and can also be observed by inspecting such sample order statistics as the median and the first and third quartiles. Figure I displays the spatial variation in the collapse of retail car sales, defined as the percentage change in retail automobile sales from 2008 to 2009 within a county. Counties in New England and parts of the upper West experienced a smaller drop in retail auto sales relative to the majority of counties in the South and West.

\section{Measuring Non-BAnK DePENDENCE}

To analyze the role of non-bank financing in the collapse of car sales, we construct a measure of a county's dependence on non-bank financing. We define our measure of non-bank dependence as the ratio of the number of retail auto sales financed by non-banks to the number of all retail financed transactions in the county in the first quarter of 2008. An alternative definition of this measure is to divide the number of retail auto sales financed by non-banks by all retail transactions in the county, regardless of whether they are financed. We focus on the former measure, however, because it alleviates the concern that non-bank dependence proxies for more general credit usage and demand in a county. To wit, when dependence is defined as a share of total retail sales, it might be high in counties that use more financing, which might be correlated with demand shocks. By using non-bank-financed transactions as a share of all retail

\footnotetext{
${ }^{14}$ See Online Appendix Figure A.III.
} 
financed transactions in the county, we purge the pure financing effect and focus instead on the intensive margin of the composition of financing.

The timing of our baseline measure of non-bank dependence can also affect inference.

The first quarter of 2008 is the earliest available date that Polk records lender information. But if dealers and consumers began substituting away from non-bank financing to other lenders during this period, the baseline measure might already reflect the effects of this substitution, rather than a county's historic dependence on non-bank credit. Also, because the baseline dependence measure is based on first quarter 2008 data, seasonality in the provision of credit across lenders could lead to inaccurate estimates of a county's non-bank dependence.

These measurement concerns are valid. But they are likely to be mitigated by the relationship-based nature of non-bank auto credit, most of which consists of captive credit. Captive relationships are especially strong at the wholesale or dealership level, and can render the cross-county variation in non-bank dependence persistent, at least before the full onset of the financial crisis. Figure II plots the county-level variation in non-bank dependence, measured in the first quarter of 2008. Not surprisingly, Michigan - the headquarters of the three major domestic manufacturers and their respective captive-financing arms-has the largest share of non-bank-financed transactions in the United States. In areas where other auto manufacturers have a long-standing presence and dealers have close relationships with captives, such as in Alabama and Tennessee, captives also appear to dominate credit transactions (Holmes 1998).

To address these measurement concerns, we use data from Equifax to supplement our Polk-based baseline county-level non-bank dependence measure. Equifax, one of the three major credit bureaus in the United States, collects data on individuals' liabilities, including their car purchases, and in the version of the data set available to us, it identifies whether the source of automotive credit is a non-bank financier along with the borrower's zip code. These data are available quarterly and extend back to 2006, which enables us to construct measures of non-bank dependence at least two years before the onset of the financial crisis. ${ }^{15}$ We draw a 10 percent random sample from Equifax, which yields a panel of about three million households. As Figure III demonstrates, the quarterly growth in car sales derived from both Polk and Equifax are very similar.

\footnotetext{
${ }^{15}$ Equifax does not list the name of the credit supplier.
} 
We aggregate the Equifax data at the county level and create two measures of non-bank dependence. These measures are: (1) the ratio of non-bank financed transactions to all financed transactions in the county in the first quarter of 2008, which corresponds to the time period in the baseline Polk measure, and (2) the ratio of non-bank financed transactions to all finance transactions in 2006. Table I reports the summary statistics for the two Equifax-based measures of non-bank dependence (columns (1) and (2)); the Polk derived ratio of non-bank to all new transactions (column (3)); and the baseline ratio of non-bank to all financed transactions, also from Polk (column (4)), along with a panoply of key control variables.

The basic summary statistics suggest that non-banks account for about 40 percent of all auto purchases (column (3)) and for about 52 percent of all financed purchases (column (4)). The dependence measures derived from Equifax, as well those obtained using Polk, are very similar to each other, although the average incidence of non-bank credit appears to be a little smaller in 2006 compared to that observed in the first quarter of 2008. The cross-sectional variation in all four variables is very similar. Table A.5 in the Online Appendix reports the coefficient from regressing separately the Equifax 2008 first quarter measure of dependence separately on the other three alternative dependence variables, controlling for state fixed effects. The point estimates in these regressions range from 0.762 to 0.821 and are all statistically significant at the 1 percent level. In robustness tests we present below, we show that our baseline estimates are relatively unchanged across the alternative measures of captive dependence.

\section{IV.A. The Determinants of Non-Bank Dependence}

To understand the determinants of a county's dependence on non-bank financing we estimate cross-county regressions of non-bank dependence on a number of county-level demographic variables and report the results in Table II. The first twelve columns of Table II show the coefficient from univariate regressions of non-bank dependence on each of these variables. Counties more dependent on non-bank credit are generally more populous, have higher median income, and have greater income inequality (measured by the county's Gini coefficient). There is no evidence that economic conditions before the crisis, as proxied for by the unemployment rate in either 2006 or 2007, are correlated with dependence. Non-bank dependence is also not significantly related to the housing cycle, as measured by the change in house prices during the boom (2005-2006). 
Column (14) reports results from a multivariate regression that includes these variables jointly. There is some evidence that non-bank dependence is smaller in counties with more Whites, and the positive coefficients on both the median income and population variables remain significant.

Column (15) uses the extensive margin measure of non-bank dependence as the dependent variable: the number of non-bank financed transactions divided by the number of transactions in a county. The results confirm the concern that this extensive margin measure of dependence is potentially more affected by differential credit usage across income groups within a county; the coefficient on the median FICO score in the county is now negative and statistically significant. Borrowers with lower FICO scores were disproportionately affected by the crisis, however, and inference based on this measure of dependence might be more prone to concerns about omitted demand-side factors. ${ }^{16}$

Although the concern about the correlation between borrower credit quality and non-bank dependence is valid, it is important to put this concern in context. By the first quarter of 2007 only 15 percent of GMAC's U.S.-serviced consumer asset portfolio was considered nonprime; GMAC was the biggest non-bank automotive lender at that point. ${ }^{17}$ That is, the largest non-bank automotive lenders did not concentrate on subprime borrowers, but the vast majority of car buyers who relied on non-bank credit were safer borrowers who had lower sensitivity to the housing cycle.

\section{Non-Bank Credit And the Collapse of Auto Sales: The AgGRegate Evidence}

In this section we present county-level evidence of the relation between non-bank credit and car sales during the crisis.

\section{V.A. Sales Financed by Non-Bank Creditors}

We analyze the effect of non-bank credit dependence on the change in automotive sales financed by non-bank creditors between 2008 and 2009. We use the following baseline regression specification:

$$
\log (\text { cars })_{2009 i}-\log (\text { cars })_{2008 i}=\alpha_{0}+\alpha_{1} \times \text { dependence }_{i}+X_{i} \beta+S_{i}+e_{i}
$$

\footnotetext{
${ }^{16} \mathrm{We}$ are grateful to an anonymous referee for suggesting this test and the intensive measure of dependence.

${ }^{17}$ See GMAC LLC, 8-K, April 26, 2007, File No. 001-03754.
} 
where the dependent variable is the difference in the log number of cars financed by non-bank creditors in county $i$ between 2008 and 2009. Our main explanatory variable is the county's dependence on non-bank financing. The baseline county-level specifications use Polk data and define dependence as the ratio of retail sales financed by non-banks to all financed transactions in the county, observed in 2008 Q1 - the earliest date for which Polk data identifies the credit provider in the transactions.

Table III presents the results from estimating different variants of the model with standard errors (in parentheses) clustered at the state level. We also weight these county-level regressions by the population in the county circa $2009 .{ }^{18}$ All of the specifications include state fixed effects (the vector $\boldsymbol{S}$ ) to absorb time-invariant state heterogeneity. Most of our specifications also control for county-level economic and demographic variables that are included in the vector $\boldsymbol{X}_{i}{ }^{19}$ Our main coefficient of interest is $\alpha_{1}$, which measures the effect of non-bank credit dependence on car sales during the crisis.

Column (1) of Table III presents the results of regression (1) using demographic and economic county-level controls as proxies for local demand, but excludes state fixed-effects. As column (1) illustrates, the non-bank dependence coefficient is economically and statistically significant. A one standard deviation increase in non-bank dependence is associated with a 3.5 percentage point or 0.17 standard deviation decline in the growth in non-bank financed transactions over this period. Alternatively, moving from a county at the 25 th to the 75 th percentile in non-bank credit dependence is associated with a 5 percentage point drop in the growth in non-bank financed transactions. The non-bank dependence coefficient is only slightly smaller when adding state fixed effects (column (2)), but in what follows all specifications use state-level fixed effects to absorb potentially relevant regulatory, geographic, and other timeinvariant state-level factors.

We control for log median income since the demand for cars might be higher in counties with higher household income. Similarly, we control for the number of African American and White residents, given the evidence that race might affect access to automotive credit (Barron,

\footnotetext{
${ }^{18}$ Although our results hold if we use regular OLS regressions, we weight our regressions by population to account for county size (see, e.g., Autor and Dorn 2013; and Mian and Sufi 2014a).

${ }^{19}$ Table I reports summary statistics for the explanatory variables used in these regressions.
} 
Chong, and Staten 2008; Einav, Jenkins, and Levin 2013). ${ }^{20} \mathrm{We}$ also add income inequality, as measured by the Gini coefficient, as a control variable in our regressions. The majority of those who relied on non-bank credit were safer borrowers with lower sensitivity to the housing cycle. But because non-banks might be more likely to serve lower-credit-quality borrowers, who in turn might have been more exposed to the Great Recession, we control for the median credit score in the county using data from Transunion. Credit scores in a county might endogenously respond to any credit supply disruptions, and as with the non-bank dependence variable, our baseline specification uses the median credit score observed in 2008 Q1 - in the robustness section we show that these results are unchanged when using alternative measures of borrower credit quality.

A county's employment structure could also drive unobserved demand shocks. In counties with strong employment links to the automotive sector, the demand for cars might endogenously vary with the health of that sector. At the same time, these counties might also have higher levels of non-bank dependence because of these automotive linkages. Figure II shows, for example, that counties in Michigan — the headquarters of the "big three"—as well as counties in states where auto manufacturers have a long-standing presence, such as Alabama, Indiana, Kentucky, and Tennessee, also have the largest share of non-bank-financed transactions in the United States. ${ }^{21}$ We thus add the fraction of employment in the automotive sector as a control variable to the regression in columns (1) and (2).

Among these demographic and economic variables, we find that the number of African American residents in the county is positively correlated with the number of car sales financed by non-bank lenders. Also, as one might expect, the credit quality of borrowers within a county is positively correlated with the growth in non-bank-financed transactions. In the Online Appendix we combine the 2005-2009 ACS with county-level data from the 2000 census in order to compute the changes in median income, poverty rate, overall population, and African American population within counties over time. In supplementary analysis presented in Table A.6, column (1), we show that using the changes instead of the level of these sociodemographic

\footnotetext{
${ }^{20}$ Charles, Hurst, and Stephens (2010) document that minorities, in particular African Americans, are more likely to receive auto loans from financing companies and pay, on average, higher interest rates on those loans. One plausible explanation for this pattern is that minorities have, on average, lower credit scores and therefore are more likely to receive financing from captives. For a detailed analysis of subprime auto-lending contracts, see Adams, Einav, and Levin (2009); and Einav, Jenkins, and Levin (2012).

${ }^{21}$ Appendix A provides a detailed description of the construction of the variables and their sources.
} 
control variables does not change the point estimate on the non-bank dependence variable.

We next incorporate household balance sheet control variables into our analysis. There is a burgeoning literature on the effect of home prices, household leverage, and net worth on local demand and employment (see Mian and Sufi 2011, 2014a; and the broader discussion in Mian and Sufi 2014b). Some of this literature has also directly connected car purchases to householdlevel changes in debt service (DiMaggio, Kermani, and Ramcharan 2014; Keys et al. 2014). To the extent that our measure of non-bank dependence is correlated with the household balancesheet-driven demand channel, estimates of the dependence coefficient might be biased.

Column (3) of Table 3 adds the 2009 county-level unemployment rate as well the median debt-to-income ratio for households in a county in 2006 to the control variables used in columns (1) and (2). ${ }^{22}$ These data are available for a smaller subsample of counties, reducing the sample size from 2,825 in column (1) to 2,056 counties in column (2). Yet the negative impact of nonbank dependence remains robust, with statistical significance at the 1 percent level and a point estimate that is very close to the one obtained in column (1). Since unemployment and leverage might be highly correlated, in Online Appendix Table A.6, columns (2) and (3), we include these variables in separate regressions; the results are unchanged.

House price dynamics was a chief catalyst behind the collapse in household demand. To address further concerns about latent demand, Column (3) directly controls for the average change in home prices in a county from 2008 to 2009. Including this variable further reduces the sample size, but as Column (4) of Table 3 demonstrates, our main finding is little changed. The house price change point estimate is positive, though imprecisely estimated, and suggests that a one standard deviation increase in house prices is associated with a 0.05 standard deviation increase in the growth in non-bank-financed transactions. In Online Appendix Table A.6, column (4), we also include an interaction term between household leverage and house price changes in the county-our basic results remain unchanged.

Last, in column (4) we add the change in household net worth between 2006 and 2009 as a control variable. Mian and Sufi (forthcoming) show that the deterioration in household balance sheets, as measured by county-level changes in household net worth, might have had a significant negative impact on local demand. Including this variable attenuates the sample size considerably, but our main results again remain unchanged. In summary, we have included a

\footnotetext{
${ }^{22}$ We thank Amir Sufi for providing us debt to income ratio data.
} 
panoply of variables associated in the literature with the household demand channel, and consistent with a credit supply shock, Table III shows that non-bank financed auto sales fell in those areas where borrowers were more heavily dependent on non-bank automotive credit.

\section{V.2. Non-Bank Dependence, Substitution, and Total Auto Sales}

Here we examine the impact of non-bank dependence on sales financed by traditional deposit-taking institutions, as well as on total auto sales. If non-bank dependence proxies for latent demand, then a demand-side shock should induce a negative correlation between non-bank dependence and the growth in car sales, regardless of the lender's source of funds. In contrast, a decline in the supply of non-bank credit could prompt banks and credit unions to increase their financing of automobiles in areas most affected by the loss of non-bank credit. When using the growth in bank-financed transactions as the dependent variable, this substitution would in turn lead to a positive coefficient on the non-bank dependence variable. Such a change in the sign of the coefficient would then be hard to reconcile with a "latent demand" interpretation of non-bank dependence.

Panel (B) of Online Appendix Table A.1 provides aggregate evidence consistent with substitution from non-bank credit to deposit-taking institutions during the crisis. The auto loan market share of finance companies - the bulk of which is captive finance-was 51.3 percent in 2005 and declined to just 41.3 percent and 36.7 percent, respectively, in 2009 and 2010. In contrast, the combined auto loan market share of credit unions and commercial banks rose from 44.9 percent in 2005 to 56.2 percent and 61.1 percent, respectively, in 2009 and 2010.

We test the substitution hypothesis directly in Table IV. We use the same empirical specification as in column (1), but we redefine the dependent variable as the change in the number of cars financed by banks and credit unions within a county between 2008 and 2009. Similar to the analysis presented in Table III, standard errors (in parentheses) are clustered at the state level, and the regressions are weighted using county population. We use the same set of explanatory variables that are in column (2) of Table III in the columns of Table IV. ${ }^{23}$ As column (1) of Table IV illustrates, the non-bank dependence point estimate is now positive and statistically significant. A one standard deviation increase in captive dependence is associated with a 2.6 percentage point or 0.15 standard deviation increase in bank-financed transactions in the county. In Table A.7 of the Online Appendix we repeat the analysis in column (1) of Table

\footnotetext{
${ }^{23}$ For brevity, we do not report the coefficients on the socioeconomic and demographic controls in Table IV.
} 
IV for each of the specifications in Table III and find positive and statistically significant point estimates of non-bank dependence in every specification. The evidence of partial substitution from non-bank providers of credit to traditional deposit-taking institutions lends additional credence to the credit supply shock.

Next, we analyze the aggregate consequences of the contraction in non-bank credit supply. To do so, we redefine the dependent variable as the log change in the number of all car sales in a county between 2008 and 2009, regardless of whether they were financed or what the source of financing was. As Column (2) of Table IV demonstrates, the dependence coefficient is negative and statistically significant. A one standard deviation increase in non-bank dependence is associated with a 1 percentage point or 0.08 standard deviation decline in the growth in new car transactions over this period.

The implied economic impact of non-bank dependence on sales appears sizable. For each county we multiply its dependence on non-bank financing by the dependence coefficient from column (2). This product yields each county's predicted growth in total car sales, as determined by the county's degree of non-bank dependence. Multiplying this predicted growth rate by the level of sales in 2008 within the county gives the predicted change in car sales. Summing up across all counties suggests that the distress among non-banks might account for a drop of about 478,776 cars in 2009 relative to 2008 sales; in our sample, 8.1 million cars were sold in 2008 and 6.5 million in 2009. This implies that the liquidity shock to non-bank financing capacity can potentially explain 31 percent of the drop in car sales in 2009 relative to 2008.

\section{V.C. Measurement of Non-Bank Dependence and Robustness Tests}

We now check that our results are robust to alternative definitions of the timing of the non-bank dependence measure. Our baseline Polk measure is calculated using 2008 Q1 data, which might already reflect some credit substitution from non-bank to depository institutions and hence might not fully represent dependence on non-bank entities within the county. We address this concern in column (3) of Table IV. We use the same specification as in column (2) of Table IV but use the Equifax-derived non-bank dependence measure, calculated using 2006 data, instead of the baseline Polk measure. This measure precedes the crisis, is computed over a full year, and likely measures non-bank dependence more precisely.

The point estimate in column (3) is negative and significant and is larger than the baseline estimate in column (2) (-0.117 compared to -0.0926). A one standard deviation 
increase in this measure of non-bank dependence is associated with a 1.9 percentage point or 0.16 standard deviation decline in the growth in total car sales. Computing non-bank dependence based on Equifax data observed in 2008 Q1 (column (4)) yields a point estimate that is similar to that of column (2). In column (5) we use the extensive margin measure of non-bank dependence from Polk-non-bank-financed transactions to all transactions-observed in 2008 Q1 and find similar results. The results presented in Table IV demonstrate that the economic impact of the loss of non-bank financing capacity appears significant and robust across various measures of non-bank dependence from different sources.

Our baseline results are robust to the inclusion of the median Transunion-based FICO score in the county, but to assuage lingering measurement concerns, we turn again to Equifax micro-level data. Using these data, we calculate the median credit score for those borrowers who obtained non-bank automotive credit in the county in 2008 Q1, which allows us to measure more accurately the credit quality of non-bank customers. As column (6) shows, the point estimate on the baseline measure of dependence is little changed, and the Equifax-derived measure of borrower credit quality adds little information beyond the more general Transunion credit quality variable.

We next investigate the sensitivity of these results to the timing of the collapse in auto sales. Because the Polk data set does not identify the source of credit before 2008 Q1, we have defined the collapse in car sales as the change in sales between 2008 and 2009. Given that the trough in annual sales occurred in 2009, this approach provides a reasonable approximation for the decline in auto sales (see Figure A.2). Nevertheless, disruptions in the ABCP market started in late 2007, and car sales began falling in 2008. As a robustness exercise, we use the log difference in car sales in 2009 relative to 2007 as the dependent variable in column (7) of Table IV. As the final column of the table demonstrates, the non-bank dependence coefficient is similar to the one reported in column (2). A one standard deviation increase in non-bank dependence is associated with a 1.3 percentage point or 0.08 standard deviation decline in the growth in car sales, measured between 2007 and 2009.

The panel structure of the data can also illuminate the timing of the collapse in car sales. To this end, we regress the quarterly growth in new car sales within a county from 2006 Q1 through 2009 Q4. We include the baseline county-level controls along with our non-bank dependence measure. We interact the non-bank coefficient with quarter dummies to permit the 
impact of non-bank dependence to vary by quarter over the sample period. These coefficients, along with the 95 percent confidence bands — in dashed lines_-are plotted in Figure IV.

As the figure shows, in 2006, when non-bank lenders were in general not financially constrained, car sales growth was positive in those counties where borrowers were more dependent on non-bank credit. The coefficient turns negative in the final quarter of 2007 as the ABCP market became stressed and again in the quarters around the collapse of Lehman Brothers. Consistent with the notion that the shutdown of the ABCP conduits of the major automotive captive financing arms in early 2009 might have greatly increased financing constraints among non-bank lenders, the coefficient on non-bank dependence becomes even more negative in early 2009.

Changes in MMF flows-mutual funds that invest in short-term securities-over time can also shed light on the timing of the collapse in car sales (Figure A.4). Because MMFs were the principal source of funding for many securitization conduits, we would expect that when net flows into MMFs are plentiful, these funds are likely to increase their demand for non-bank automotive ABCP. Moreover, among MMFs, holdings of ABCP were highest among those that catered to institutional investors and specialized in non-Treasury securities (Kacperczyk and Schnabl 2013). In Online Appendix Table A.8, we show that car sales are more sensitive to aggregate fluctuations in short-term financing conditions-primarily flows into non-Treasury institutional MMFs - in those counties more dependent on non-bank credit.

In additional robustness tests, we repeat the main specification in column (2) of Table IV for each of the four broad geographic census regions and report results in Online Appendix Table A.9. Apart from the Northeast, where the small number of observations renders the estimates unreliable, the point estimate on non-bank dependence is negative across the regions, though imprecisely estimated when the sample size shrinks. Online Appendix Tables A.10A, A.10B, and A.10C consider a battery of additional robustness tests. Table A.10A replicates the robustness exercises from Table III using total car purchases as the dependent variable; the economic significance of the non-bank dependence coefficient is stable, but the coefficient becomes more imprecise when the sample size declines, and the regressions are weighted by population. Table A.10B conducts the same exercise, but without the population weights; the non-bank dependence point estimate is negative and significant. Finally, Table A.10C repeats this exercise using the potentially more accurate non-bank dependence measure from Equifax (in 
2006). Using the 2006 Equifax-based measure, we find that the point estimates are negative and robust across the various specifications even with the smaller sample sizes and when weighted by population.

\section{V.D. Make Heterogeneity and County Fixed Effects}

We now analyze the heterogeneity of the effect of non-bank dependence on auto sales across the three largest auto manufacturers. ${ }^{24}$ In the first nine columns of Table V, we restrict our analysis to one automaker in each regression and estimate specifications similar to regression (1) with the same set of control variables as in column (2) of Table III. Non-bank dependence is defined as a county's dependence on non-bank credit for each of the automakers based on sales financed in 2008 Q1. Likewise, each of the dependent variables is calculated using the corresponding auto sales of GM, Ford, or Toyota. The table reports results for the three largest automakers in the United States: GM, columns (1)-(3); Ford, columns (4)-(6); and Toyota, columns (7)-(9).

The dependent variable in column (1) of Table V is the change in total GM sales within a county from 2008 to 2009. As the table shows, the point estimate on dependence is negative and significant, suggesting that the decline in GM sales was larger in those areas more dependent on GMAC - the main non-bank provider of credit for GM cars: a one standard deviation increase in dependence is associated with a 0.14 standard deviation drop in the change in GM-branded cars sales. Column (2) shows that although GM cars financed by GMAC fell in those areas more dependent on GMAC, bank- and credit-union-financed GM sales rose sharply in those areas in which non-bank providers like GMAC were more dominant (column (3)).

The remaining columns of Table $\mathrm{V}$ repeat the basic specifications for the other two major firms in the United States: Ford and Toyota. The pattern is similar across the three largest automakers. It suggests that despite the variation in experiences across these firms, dependence on captive financing played a significant role in explaining a portion of the collapse in car sales.

Last, the richness of our data and, in particular, the availability of make- and model-level data allow us to once more gauge the extent of biased estimates due to latent county-level unobservables that might both explain the demand for cars within a county and its dependence on captive financing. We build on the fact that the automobile market is highly segmented and

\footnotetext{
${ }^{24}$ There is evidence that concerns about the long-term solvency of the automobile manufacturer could independently shape the demand for its cars (see Hortaçsu et al. 2013).
} 
thus that shocks to the demand for cars within a county could vary substantially across models, even for those sold by the same firm.

For example, some manufacturers, such as GM, offer a large number of makes and models aimed at buyers with different income levels: Chevrolet, a major submake within GM, generally sells nonluxury models that are marketed toward lower- and middle-income buyers, while Buick and Cadillac, again both GM submakes, sell more luxurious models aimed at higher-income buyers. ${ }^{25}$ As a result, the collapse in house prices and the rise in household leverage among lower-income borrowers could precipitate a drop in the demand for Chevrolet models within a county, whereas demand for Buick and Cadillac cars within the same county could be less affected since house price dynamics might have had a smaller impact on the net worth of these higher-income buyers.

Using the detailed model and make data from Polk, along with information on model types from Ward's Automotive, one of the standard purveyors of intelligence on the automotive industry, we augment our analysis to employ within-make within-county within-segment heterogeneity. Ward's Automotive identifies the market segment in which each car model competes, and we use this information to construct a county-make-segment panel: the number of cars that each make sold within each county in each market segment. The market segmentation in the industry can be highly detailed, and Ward's lists thirty segments. This level of granularity can, however, lead to a large number of missing observations in our data set, as specialized models, such as the Chevrolet Corvette, tend to have a small number of sales in a limited geographic area. We thus collapse the thirty segments in Wards into eight broad market segments that correspond to the Insurance Institute for Highway Safety's classification: small cars; mid-sized cars; large cars; luxury cars; small utility vehicles; mid-sized utility vehicles; large utility vehicles; and luxury utility vehicles. ${ }^{26}$

With information on county, make, and segment, we can include make fixed effects, county fixed effects, and county-segment fixed effects. Make fixed effects allow us to absorb any shocks to make-level sales that affects all counties and segments, such as the potential insolvency of a make, while county fixed effects absorb county-specific time-invariant factors

\footnotetext{
${ }^{25}$ Even within some submakes such as Chevrolet, some models, such as the Corvette, are aimed at richer buyers. Bricker, Ramcharan, and Krimmel (2014) and the references contained therein discuss cars, status, and the marketing of cars in the United States.

${ }^{26}$ Appendix B provides more details on how the Ward's data are merged with Polk.
} 
that affect sales of all cars equally within the county. For example, a county's exposure to the "cash for clunkers" program, as determined by the preexisting fraction of "clunkers" in the county's automobile stock, could be correlated both with sales in 2009 and with non-bank dependence (Mian and Sufi 2012). Similarly, a county's industrial structure, such as the degree of employment in nontraded goods, or its indirect connections to the automobile sector not measured by Bureau of Labor Statistics employment shares, could also drive demand and correlate with the non-bank credit, leading to biased estimates. County-segment fixed effects, however, absorb invariant factors that affect sales of a particular segment that vary across segments, even within the same county.

As column (10) of Table $\mathrm{V}$ demonstrates, our basic results remain the same when controlling for make and county-segment fixed effects. A one standard deviation increase in captive dependence measured is associated with about a 1.2 percentage point drop in sales in 2009. In summary, the combined evidence in Table V renders it unlikely that our results are driven by omitted county or automaker factors. More important, column (10) shows that our results hold when we compare cars that are sold within county and auto segment, and thus it is unlikely that our captive dependence measure captures latent demand for cars.

\section{MICRO-LEVEL EVIDENCE FROM EQUIFAX}

\section{VI.A. Controlling for Individual FICO Scores}

Our county-level analysis provides evidence that illiquidity among non-bank lenders had a significant adverse effect on car sales. Although these results are robust to the inclusion of various measures of household demand and the housing cycle, there remains a concern that county-level variation in non-bank dependence might reflect compositional differences in borrower credit quality and latent demand between non-bank and bank borrowers. Because of these differences, borrowers from captive leasing companies and other sources of non-bank credit might be more likely to face a contraction in their credit limits imposed by other lenders, such as credit card companies. Thus, rather than reflecting the effects of diminished non-bank financing induced by illiquidity in short-term funding markets, these results might be an artifact of a more general contraction in credit to risky borrowers.

To address these concerns, we turn to individual-level data from Equifax. Equifax records information about an individual's liabilities_-automotive debt, mortgages, student loans, 
credit card debt, and credit card borrowing limits—along with the individual's age, dynamic FICO score, and zip code of residence. In the case of automotive debt, the data set also identifies whether credit was obtained from a non-bank lender or a depository institution. We use a 10 percent random sample from Equifax that we observe quarterly from 2006 Q1 through 2009 Q4-a panel of about three million individuals.

These micro-level individual data enable us to study how exposure to non-bank financing - the degree of non-bank dependence in the county-might have affected an individual's likelihood of obtaining non-bank automotive credit, controlling directly for the borrower's FICO score, as well as other measures of borrower credit quality. We present summary statistics for the Equifax sample on credit card balances, credit card limits, FICO score, year of birth, and homeownership rate in Table VI for counties below and above the non-bankdependence median. The Equifax-based summary statistics in Table VI are consistent with the notion that counties more dependent on automotive non-bank finance generally have populations that register higher credit card balances and lower credit limits, with concomitantly lower credit scores. The populations in the more non-bank-dependent counties are also marginally younger and are less likely to own a home or, at least, to have mortgage-related debt.

These potentially important differences in borrower composition among users of nonbank credit render the household-level tests even more important. By including the individual's FICO score, age, and homeownership status, as well as credit card balances and revolving credit limits, we can directly control for key measures of borrower credit quality. That is, unlike the more aggregate county-level evidence, these individual-level controls restrict the potential for biased estimates that might arise from latent demand and unobserved differences in the composition of borrowers between non-bank lenders and other sources of automotive credit. Also, the panel structure of these tests, which allow us to hold constant these borrower-level observables and study how the variation in non-bank financing capacity over the crisis period might have affected individual-level credit access, can offer powerful evidence of the credit supply channel.

In column (1) of Table VII we use a linear probability model to estimate the probability that an individual obtains non-bank automotive credit in a given quarter in 2008-2009. Building on the earlier panel-level results (Figure IV), which show that captive financing capacity changed substantially over this period, we allow the coefficient on non-bank dependence at the 
county level to vary by quarter. And in addition to the household-level controls, we include state and year-by-quarter fixed effects, and we cluster standard errors at the state level.

The evidence in column (1) suggests that, with individual FICO score, age, credit card balance, and mortgage status held constant, individuals are more likely to obtain non-bank automotive credit when they live in a county with a greater dependence on non-bank credit. Strikingly, however, the impact of non-bank dependence on the probability of obtaining captive credit changes considerably over the sample period. The coefficient drops by about 28 percent from the first quarter of 2008 to the final quarter of that year. It rebounds slightly in the beginning of 2009 but drops sharply toward the end of the year, by a factor of almost eight relative to its peak in the first quarter of 2008, and becomes insignificant in the third quarter of 2009.

To understand better the timing of the shock at the individual level, we extend the sample back to 2007. These results are reported in column (2) of Table VII. Although turbulence in the housing market and deleveraging already began in 2007, we find no evidence of a decline in the non-bank coefficient during this period (Mayer, Pence, and Sherlund 2009). Similar to the county-level results (Figure IV), the non-bank dependence coefficient becomes significantly negative for the first time in the second quarter of 2008. Also consistent with Figure IV, this point estimate remains negative throughout the remaining quarters. This suggests that our findings are unlikely to be driven by omitted variables pertaining to the local housing market and its effects on consumer credit. In column (1) of Online Appendix Table A.11A we confirm this result by restricting the sample to 2007. These results are also little changed if we model the persistence in car-buying behavior with a lagged dependent variable or if we control for borrower observables using lagged values_-observed either one quarter before or at the beginning of year.

Column (3) of Table VII focuses on aggregate car sales over 2008-2009. The dependent variable is the probability that an individual obtains automotive credit, regardless of the source of financing - excluding cash purchases, since Equifax has no information on these. As with column (1), for individuals living in a more non-bank-dependent county, the likelihood of obtaining automotive credit fell sharply at the end of 2009. In particular, the non-bankdependence coefficient declines by about 33 percent in the third quarter of 2009 compared to its peak in the first quarter of 2008. This decline is less than the eightfold drop observed in column 
(1), as other sources of automotive financing might have substituted for the loss of non-bank financing.

We now consider a number of robustness tests. Table VI suggests that counties more dependent on non-bank finance might differ from those counties more dependent on bank credit. To check whether non-bank dependence might more generally proxy for credit conditions within a county, column (4) of Table VII uses the probability that the individual buys a home in the quarter as the dependent variable. If the non-bank-dependence variable reflects local credit conditions, such as the supply of mortgage financing, then the non-bank-dependence coefficients should also evince a similar pattern to that observed in columns (1) and (2). The estimates in column (4) show no such pattern. Instead, the non-bank dependence coefficient is insignificant. That said, the demand for houses might have begun declining before the first quarter of 2008, and in column (2) of Online Appendix Table A.11A we repeat the analysis for 2007-2009. The non-bank-dependence coefficient remains insignificant.

To check further whether non-bank dependence might proxy for other types of binding credit constraints at the individual level, column (5) of Table VII uses the log of the individual's credit card limit as the dependent variable. ${ }^{27}$ If anything, the non-bank-dependence point estimate becomes less negative and even positive over time as the economy exited the recession in the second half of 2009. As an alternative measure, we let the credit limit equal one for those households with positive limits and zero otherwise. We also consider the credit utilization ratethe ratio of credit balances to limits-among those individuals with positive credit limits. In both cases, there is no evidence that non-bank dependence might proxy for other types of binding credit constraints as demonstrated in columns (3) and (4) of Online Appendix Table A.11A.

Last, we aggregate the individual-level data up to the county to check further whether non-bank dependence might be associated with broader credit outcomes. That is, we examine whether the change in mortgage balances between 2008 and 2009 within a county, or the log level of mortgage balances in 2009, is correlated with the county's non-bank dependence. Similarly, we aggregate up credit card balances and examine whether the change in the total credit card balance between 2008 and 2009 at the county-level is correlated with non-bank dependence. In all cases the non-bank dependence coefficient is not significant. These results are presented in Online Appendix Table A.11B.

\footnotetext{
${ }^{27}$ We transform the credit card limit to $\log (1+$ credit card limit).
} 


\section{VI.B. Captive Dependence and Local Auto Sales Stratified by FICO}

Reputational motives as well as declining collateral values can prompt financial institutions to tighten credit policies after an adverse shock. ${ }^{28}$ Therefore, to gauge further the robustness of our results and understand better the underlying channels through which the financing shock might have led to the drop in car sales, we examine how the impact of exposure to non-bank financing on the likelihood of obtaining non-bank automotive credit might have varied by borrower credit quality. To this end, we estimate the baseline specification in column (1) of Table VII separately for borrowers with different FICO scores and report the results in Table VIII. We stratify the Equifax data by FICO quartiles: column (1) uses the subsample of borrowers in the lowest quartile - those with a FICO score below 603; column (2) uses borrowers from the second quartile, between 603 and 706; column (3) focuses on the third quartile, 706-784; and column (4) contains those borrowers with scores above 784.

Across all borrower FICO categories, the point estimates imply that access to non-bank automotive credit declined sharply toward the end of 2008 and again in the second half of 2009. For example, even among those borrowers in the top quartile, the non-bank dependence coefficient, although positive in the first quarter of 2008, declines by about 43 percent in the third quarter of 2009 relative to its value in the first quarter of 2008. But consistent with the idea that credit policy might have become especially conservative after a shock, the decline in nonbank credit access appears to be most severe for those borrowers with FICO scores in the bottom quartile. From column (1) the overall impact of dependence in the third quarter of 2009 is negative, suggesting that these borrowers were less likely to obtain captive credit in those areas more dependent on non-bank financing.

\section{CONCLUSION}

There is growing consensus that the financial crisis of 2008-2009 shared many elements of a bank run, but one concentrated in the non-deposit-taking sectors of the financial system that primarily relied on short-term funding. Less well understood, however, are the economic consequences of the runs in these funding markets. Focusing on the U.S. automobile sector, we show that the illiquidity in short-term funding markets during the crisis might have played an

\footnotetext{
${ }^{28}$ See Bernanke and Gertler (1989), Rajan (1994), and the loan level evidence from the financial crisis in Ramcharan, van den Heuvel, and Verani (2014) and Ramcharan and Crowe (2013).
} 
important role in limiting the supply of non-bank automotive credit, such as automotive captive lenders, during the financial crisis. In particular, our estimates suggest that this contraction in the supply of non-bank automotive credit, largely due to the illiquidity in the ABCP market, might explain about one-third of the collapse in car sales during this period, possibly further worsening the financial situation of the major U.S. automakers.

This evidence is related to the broader literature on how funding disruptions and other balance-sheet shocks to traditional financial institutions might affect credit availability to the real economy. Our results also suggest that although shocks to the balance sheet of households might account for a substantial part of the decline in economic activity after the crisis, illiquidity in short-term funding markets and balance shocks to both bank and non-bank institutions might also explain some of this decline, despite a myriad of policy interventions. We leave it to future research to measure more precisely the efficacy of these interventions.

NORTHWESTERN UNIVERSITY AND NBER

FEDERAL RESERVE

USC

SUPPLEMENTARY MATERIAL

An Online Appendix for this article can be found online. 


\section{REFERENCES}

Acharya, Viral V., and Nada Mora, “A Crisis of Banks as Liquidity Providers,” Working Paper, July 2013 (forthcoming in Journal of Finance).

Acharya, Viral V., Phillip Schnabl, and Gustavo Suarez, "Securitization without Risk Transfer," Journal of Financial Economics, 107 (2011), 515-536.

Adams, William, Liran Einav, and Jonathan Levin, "Liquidity Constraints and Imperfect Information in Subprime Lending," American Economic Review, 99 (2009), 49-84.

Allen, Franklin, and Douglas Gale, "Financial Contagion," Journal of Political Economy, 108 (2000), $1-33$.

Allen, Franklin, Ana Babus, and Elena Carletti, "Financial Crises: Theory and Evidence," Annual Review of Financial Economics, 1 (2009), 97-116.

Autor, David H., and David Dorn, "The Growth of Low-Skilled Service Jobs and the Polarization of the US Labor Market,” American Economic Review, 103 (2013), 1553-1597.

Barron, John M., Byung-Un Chong, and Michael E. Staten, "Emergence of Captive Finance Companies and Risk Segmentation in Loan Markets: Theory and Evidence," Journal of Money, Credit and Banking 40 (2008), 173-192.

Becker, Bo, and Victoria Ivashina, “Cyclicality of Credit Supply: Firm Level Evidence,” Journal of Monetary Economics 62 (2014), 76-93.

Bernanke, Ben, and Mark Gertler, “Agency Costs, Net Worth and Business Fluctuations," American Economics Review 79 (1989), 14-31.

Bricker, Jesse, Rodney Ramcharan, and Jacob Krimmel, "Signaling Status: The Impact of Relative Income on Household Consumption and Financial Decisions," August 2014, available at SSRN: http://dx.doi.org/10.2139/ssrn.2435503.

Brunnermeier, Markus K., “Deciphering the Liquidity and Credit Crunch 2007-2008,” Journal of Economic Perspectives, 23 (2009), 77-100.

Calder, Lendol, Financing the American Dream: A Cultural History of Consumer Credit (Princeton: Princeton University Press, 1999).

Campbell, Sean, Daniel Covitz, William Nelson, and Karen Pence, "Securitization Markets and Central Banking: An Evaluation of the Term Asset-Backed Securities Loan Facility," Journal of Monetary Economics, 58 (2011), 518-531. 
Charles, Kerwin Kofi, Erik Hurst, and Melvin Stephens, "Rates for Vehicle Loans: Race and Loan Source," American Economic Review, 98 (2010), 315-320.

Chodorow-Reich, Gabriel, “The Employment Effects of Credit Market Disruptions: Firm-Level Evidence from the 2008-9 Financial Crisis," Quarterly Journal of Economics, 129 (2014), 1-59. Cornett, Marcia Millon, Jamie John McNutt, Philip E. Strahan, and Hassan Tehranian, "Liquidity Risk Management and Credit Supply in the Financial Crisis," Journal of Financial Economics, 101 (2011), 297-312.

Covitz, Daniel, Nellie Liang, and Gustavo A. Suarez, "The Evolution of a Financial Crisis: Collapse of Asset-Backed Commercial Paper Market," Journal of Finance, 68 (2013), 815-848.

Diamond, Douglas W., and Raghuram G. Rajan, “Liquidity Shortages and Banking Crisis,” Journal of Finance, 60 (2005), 615-647.

—_, "Fear of Fire Sales, Illiquidity Seeking, and Credit Freezes," Quarterly Journal of Economics, 126 (2011), 557-591.

DiMaggio, Marco, Amir Kermani, and Rodney Ramcharan, "Monetary Policy Pass-Through: Household Consumption and Voluntary Deleveraging," 2014, Working Paper, Columbia Business School.

Einav, Liran, Mark Jenkins, and Jonathan Levin, "Contract Pricing in Consumer Credit Markets," Econometrica, 80 (2012), 1387-1432.

— , "The Impact of Credit Scoring on Consumer Credit," RAND Journal of Economics, 44 (2013), 249-274.

Gao, Pengjie, and Hayong Yun, "Liquidity Backstop, Corporate Borrowing, and Real Effects,” 2013, Working Paper.

Goolsbee, Austan, and Allan Krueger, “A Retrospective Look at Rescuing and Restructuring General Motors and Chrysler," Journal of Economic Perspectives, 29 (2015), 3-24.

Gorton, Gary B., Slapped by the Invisible Hand: The Panic of 2007 (Oxford: Oxford University Press, 2010).

Gorton, Gary B., and Andrew Metrick, "Securitized Banking and the Run on Repo,” Journal of Financial Economics, 104 (2012), 425-451.

Haugh, David, Annabelle Mourougane, and Olivier Chatal, “The Automobile Industry in and beyond the Crisis,” 2010, OECD Economics Department Working Paper No. 745. 
Hortaçsu, Ali, Gregor Matvos, Chad Syverson, and Sriram Venkataraman, "Indirect Costs of Financial Distress in Durable Goods Industries: The Case of Auto Manufacturers," Review of Financial Studies, 26 (2013), 1248-1290.

Hyman, Louis, Debtor Nation: The History of America in Red Ink (Princeton: Princeton University Press, 2011).

Ivanshina, Victoria, and David Scharfstein, "Bank Lending during the Financial Crisis of 2008," Journal of Financial Economics, 97 (2010), 319-338.

Kacperczyk, Marcin, and Philipp Schnabl, "When Safe Proved Risky: Commercial Paper during the Financial Crisis of 2007-2009," Journal of Economic Perspectives, 24 (2010), 29-50.

Kacperczyk, Marcin, and Philipp Schnabl, “How Safe Are Money Market Funds?” Quarterly Journal of Economics, 128 (2013), 1073-1122.

Kaisha, Jidosha. Toyota: A History of the First 50 Years (Toyota City: Toyota Motor Corporation, 1988).

Khwaja, Asim Ijaz, and Atif Mian, "Tracing the Impact of Bank Liquidity Shocks: Evidence from an Emerging Market," American Economic Review, 98 (2008), 1413-1442.

Ludvigson, Sydney, “The Channel of Monetary Transmission to Demand: Evidence from the Market for Automobile Credit,” Journal of Monetary Economics, 30 (1998), 365-383.

Mayer, Christopher J., Karen M. Pence, and Shane M. Sherlund, "The Rise in Mortgage Defaults," Journal of Economic Perspectives, 23 (2009), 27-50.

Mian, Atif, and Sufi, Amir, "Household Leverage and the Recession of 2007-09," IMF Economic Review, 58 (2010), 74-114.

— , "House Prices, Home Equity-Based Borrowing, and the U.S. Household Leverage Crisis," American Economic Review, 101 (2011), 2132-2156.

_ _ "The Effects of the Fiscal Stimulus: Evidence from the 2009 Cash for Clunkers Program," Quarterly Journal of Economics, 127 (2012), 1107-1142.

_ , "What Explains the 2007-2009 Drop in Employment? The Aggregate Demand Channel," 2014a, Working Paper, Princeton University.

- House of Debt: How They (and You) Caused the Great Recession, and How We Can Prevent It from Happening Again (Chicago: University of Chicago Press, 2014b).

Mian, Atif, Kamalesh Rao, and Amir Sufi, "Household Balance Sheets, Consumption and the Economic Slump," Quarterly Journal of Economics, 128 (2013), 1687-1726. 
Mufin, Justin, and Ryan Pratt, 2015, "Who Finances Durable Goods and Why It Matters: Captive Finance and the Coase Conjecture,” Working paper, Yale School of Management.

Phelps, Clyde William, The Role of the Sales Finance Companies in the American Economy (Baltimore: Commercial Credit, 1952).

Pierce, Lamar, "Organizational Structure and the Limits of Knowledge Sharing: Incentive Conflict and Agency in Car Leasing,” Management Science, 58 (2012), 1106-1121.

Pozsar, Zoltan, Tobias Adrian, Adam Ashcraft, and Hayley Boesky, "Shadow Banking," 2010, FRBNY Staff Report No. 458.

Rajan 1994.

Rajan, Raghuram, and Rodney Ramcharan, “The Anatomy of a Credit Crisis: The Boom and Bust in Farm Land Prices in the United States in the 1920s." American Economic Review, 105 (2015), $1439-1477$.

— , "Crises and the Development of Economic Institutions: Some Microeconomic Evidence," forthcoming, American Economic Review, Papers and Proceedings.

—_ "Local Financial Capacity and Asset Values: Evidence from Bank Failures," forthcoming, Journal of Financial Economics.

Ramcharan, Rodney, and Christopher Crowe, "The Impact of House Prices on Consumer Credit: Evidence from an Internet Bank," Journal of Money, Credit and Banking, 45 (2013), 1085-1115.

Ramcharan, Rodney, Skander J. van den Heuvel, and Stéphane Verani, "From Wall Street to Main Street: The Impact of the Financial Crisis on Consumer Credit," forthcoming, Journal of Finance.

Shleifer, Andrei, and Robert W. Vishny, "Unstable Banking,” Journal of Financial Economics, 97 (2010), 306-318.

Sloan, Alfred, My Years with General Motors (New York: Doubleday, 1964). 


\section{Appendix A: Variable Description and Construction}

For reference, the following is a list of variables used in the paper, their sources, and a brief description of how each variable is constructed.

i. African American Population: Number of African Americans in a county. (Source: American Community Survey)

ii. Assets: Total bank assets. (Source: FR Y9-C, FFIEC 031)

iii. Captive Dependence: Share of county-level retail car sales financed by captive financing companies. (Source: Polk)

iv. Captive Financed Sales: County-level retail car sales financed by captive financing companies.

(Source: Polk)

v. County Area: Size of a county in square miles. (Source: American Community Survey)

vi. Employment in Automobile Manufacturing: Divides the number of employees in the automobile sector by total employment. (Source: Quarterly Census of Employment and Wages)

vii. Gini Coefficient: Measures income inequality in a county. (Source: American Community Survey) viii. House Price Change: Annual change in the local house price index. (Source: CoreLogic)

ix. Household Leverage: County-level household debt-to-income ratio. (Source: Federal Reserve of New York)

x. Median Household Income (Source: American Community Survey)

xi. Median credit score, 2008 Q1 (Trans Union): The median FICO score in the county in 2008 Q1 from Trans Union Corporation, drawn from the entire population in the county.

xii. Median credit score, 2008 Q1 (Equifax): The median FICO score in the county in 2008 Q1 among buyers using captives for automotive credit.

xiii. Money Market Fund Flows: Quarterly net flows to (from) money market funds. (Source: Flow of Funds, Federal Reserve Board)

xiv. Non-Captive Financed Sales: County-level retail car sales not financed by captive financing companies. (Source: Polk)

xv. Percent African American: African American population divided by population. (Source: American Community Survey)

xvi. Population: Number of people in a county. (Source: American Community Survey)

xvii. Population Density: Population divided by area. (Source: American Community Survey)

xviii. Poverty Rate: Number of people living below the poverty line divided by population. (Source: U.S. Census)

xix. Retail Car Sales: The sum of retail purchases and retail leases. (Source: Polk) 
xx. Unemployment Rate: County-level labor force divided by the number of unemployed. (Source:

Bureau of Labor Statistics)

xxi. White Population: Number of Caucasians in a county. (Source: American Community Survey) 


\section{Appendix B: Auto Segment Construction}

The eight auto segments used in make-county regression (Table V) include the following models: i. Small cars (Ward's categories: lower small and upper small): BMW 128, BMW 135, Chevrolet Aveo, Chevrolet Cobalt, Dodge Caliber, Ford Focus, Honda Civic, Honda Fit, Hyundai Accent, Hyundai Elantra, Kia Forte, Kia Rio, Kia Soul, Kia Spectra, Mazda 3, Mini Cooper, Mitsubishi Lancer, Nissan Cube, Nissan Sentra, Nissan Versa, Pontiac G3, Pontiac Vibe, Saab 93, Saturn Astra, Subaru Impreza, Saturn Ion, Suzuki Aerio, Suzuki Forenza, Suzuki Reno, Suzuki SX4, Toyota Corolla, Toyota Yaris, Volkswagen GLI, Volkswagen Golf, Volkswagen Jetta, Volkswagen Rabbit, Volkswagen R32, and Volvo V50.

ii. Mid-sized cars (Ward's categories: lower middle and upper middle): Buick Lacrosse, Chevrolet Impala, Chevrolet Malibu, Chrysler Sebring, Dodge Avenger, Ford Fusion, Honda Accord, Honda FCX, Honda Insight, Hyundai Azera, Hyundai Sonata, Kia Optima, Mazda 6, Mercury Mila, Mercury Montego, Mercury Sable, Mitsubishi Galant, Nissan Altima, Pontiac G6, Pontiac G8, Pontiac Grand Prix, Saturn Aura, Subaru Legacy, Suzuki Kizashi, Toyota Camry, Volkswagen CC, Volkswagen Passat, and Volvo V70.

iii. Large cars (Ward's category: large): Buick Lucerne, Chrysler 300, Dodge Charger, Dodge Magnum, Ford

Crown Victoria, Ford Five Hundred, Ford Taurus, Kia Amanti, Mercury Grand Marquis, Mercury Monterey.

iv. Luxury cars (Ward's categories: small luxury, middle luxury, and large luxury): Acura RL, Acura TL, Acura TSX, Audi A3, Audi A4, Audi A6, Audi S4, Bentley Continental, BMW 328, BWM 335, BW 525, BMW 528, BMW 530, BMW 535, BMW 550, BMW M3, BMW M5, Cadillac CTS, Cadillac DTS, Cadillac STS, Chevrolet Monte Carlo, Hyundai Genesis, Infiniti G35, Infiniti G37, Infiniti M35, Infiniti M45, Jaguar SType, Jaguar X-Type, Lexus ES, Lexus GS, Lexus HS250H, Lexus IS, Lincoln MKS, Lincoln MKZ, Lincoln Town Car, Mercedes-Benz C-Class, Mercedes-Benz CLK-Class, Mercedes-Benz E-Class, Nissan Maxima, Toyota Avalon, Volvo S40, Volvo S60, and Volvo S80.

v. Small utility vehicles (Ward's categories: small cross/utility and small sport/utility): Chevrolet HHR, Chrysler PT Cruiser, Dodge Nitro, Honda Element, Hyundai Tucson, Jeep Compass, Jeep Liberty, Jeep Patriot, Jeep Wrangler, Kia Sportage, Land Rover LR2, Mercury Mariner, Saab 95, Suzuki Grand Vitara. vi. Mid-sized utility vehicles (Ward's categories: middle cross/utility and middle sport/utility): Chevrolet Equinox, Chevrolet Trailblazer, Dodge Journey, Ford Edge, Ford Escape, Ford Explorer, GMC Envoy, GMC Terrain, Honda CR-V, Honda Crosstour, Honda Pilot, Hyundai Santa Fe, Hyundai Veracruz, Isuzu Ascender, Jeep Commander, Jeep Grand Cherokee, Kia Borrego, Kia Rondo, Kia Sorento, Land Rover LR3, Mazda CX-7, Mazda 5, Mazda Tribute, Mitsubishi Endeavor, Mitsubishi Outlander, Nissan Murano, Nissan Pathfinder, Nissan Rogue, Nissan Xterra, Pontiac Torrent, Saturn Vue, Subaru B9 Tribeca, Subaru Forester, Subaru Outback, Suzuki XL7, Toyota 4 Runner, Toyota FJ Cruiser, Toyota Highlander, Toyota RAV4, Toyota Venza, and Volkswagen Tiguan. 
vii. Large utility vehicles (Ward's categories: large cross/utility and large sport/utility): Buick Enclave, Chevrolet Suburban, Chevrolet Tahoe, Chevrolet Traverse, Chrysler Aspen, Dodge Durango, Ford Expedition, Ford Flex, Ford Freestyle, Ford Taurus X, GMC Acadia, GMC Envoy XL, GMC Yukon, Mazda CX-9, Mitsubishi Montero, Nissan Armada, Saturn Outlook, Toyota Sequoia.

viii. Luxury utility vehicles (Ward's categories: small luxury cross/utility, middle luxury cross/utility, large luxury cross/utility, luxury middle sport/utility, and luxury large sport/utility): Acura MDX, Acura RDX, Acura ZDX, Audi Q5, Audi Q7, BMW X3, BMW X5, BMW X6, Buick Rainier, Buick Rendezvous, Cadillac Escalade, Cadillac SRX, Chrysler Pacifica, Hummer 4-PSGR Wagon, Hummer H2, Hummer H3, Infiniti EX, Infiniti FX35, Infiniti FX45, Infiniti FX50, Infiniti QX56, Land Rover LR4, Land Rover Range Rover, Lexus GX, Lexus LX, Lexus RX, Lincoln MKT, Lincoln MKX, Lincoln Navigator, Mercedes-Benz Gclass, Mercedes-Benz GL-class, Mercedes-Benz GLK, Mercedes-Benz M-class, Mercedes-Benz R-class, Mercury Mountaineer, Porsche Cayenne, Saab 9-7X, Subaru Tribeca, Toyota Land Cruiser, Volkswagen Touareg, Volvo XC60, Volvo XC70, and Volvo XC90. 


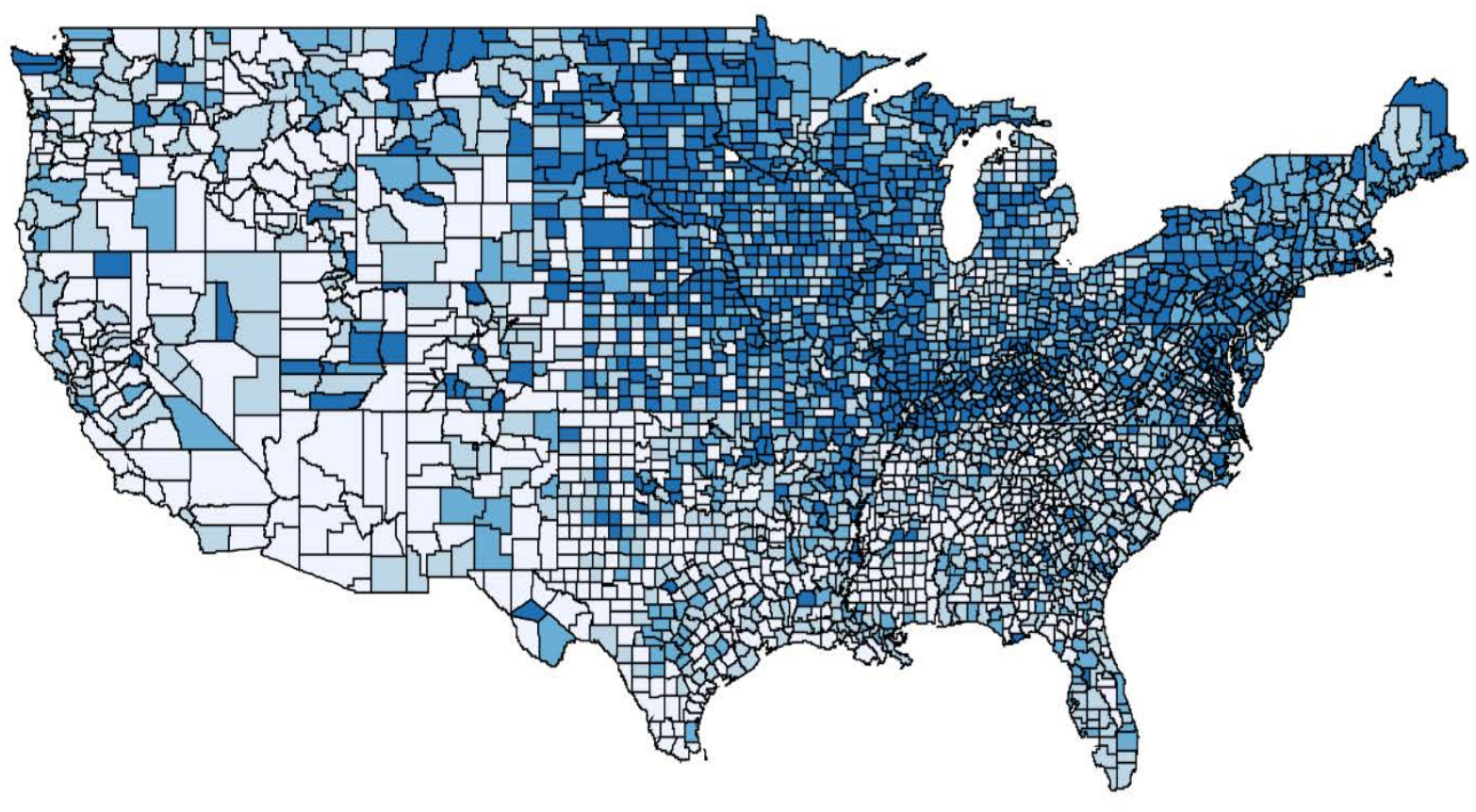

$(-.1292117,1.098612]$

$(-.2058521,-.1292117]$

$(-.2973752,-2058521]$

$[-1.386294,-2973752]$

No data

FIGURE I

County-Level Change in Retail Car Sales, 2008-2009. Retail car sales are the sum of retail leases and retail purchases in Polk. 


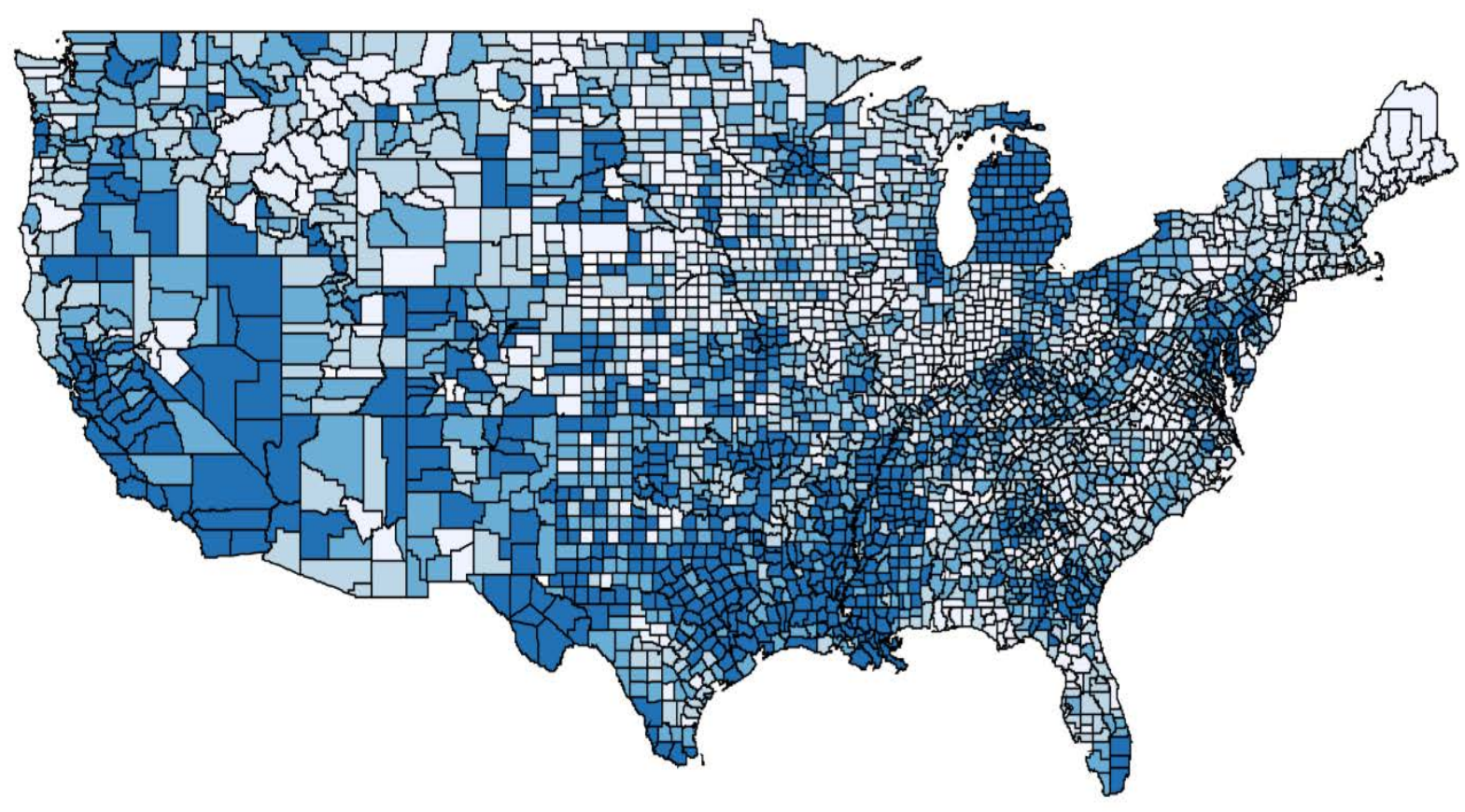

FIGURE II

County-Level Share of Retail Cars Financed by Non-Banks in 2008 Q1. Retail car sales are the sum of retail leases and retail purchases in Polk. The share is defined relative to all retail transactions in the county, regardless of the source of financing. 


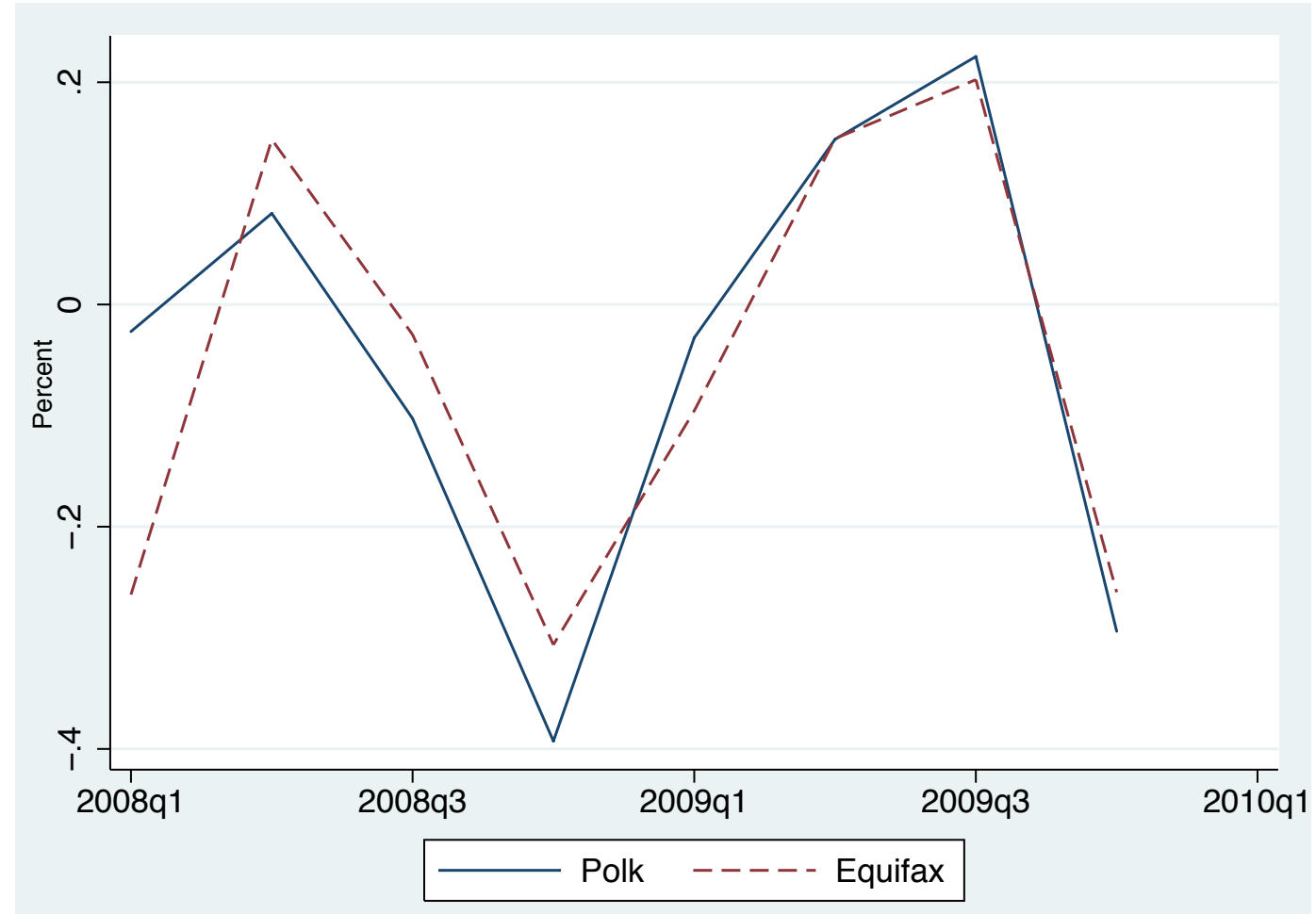

FIGURE III

Quarterly Growth in New Car Sales-Comparing Polk and Equifax. The figure plots the quarter on quarter growth in car sales, as reported by Polk and Equifax. 


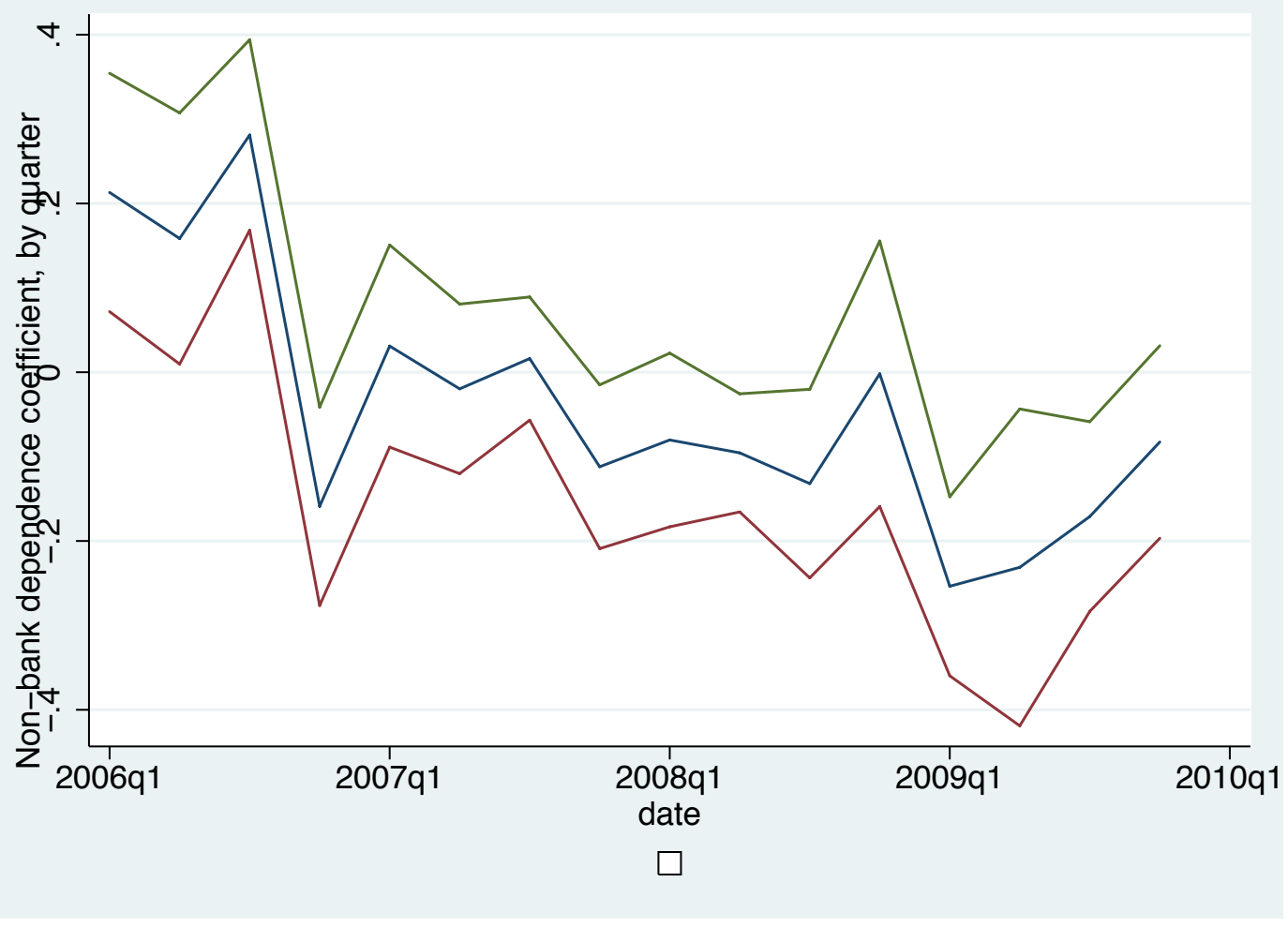

FIGURE IV

Captive Dependence and Car Sales, 2006 Q1-2009 Q4. The figure plots the coefficient—solid line—along with the 95 percent confidence band—-dashed line_-from regressing the quarterly growth in aggregate car sales — at the county level—on captive dependence (Polk), and the baseline controls from column (2) of Table III, along with year-quarter fixed effects. The captive dependence coefficient is allowed to vary by quarter over the sample period. 
TABLE I

SUMMARY STATISTICS

This table presents the summary statistics for county characteristics used in the empirical analysis. In column (1), non-bank dependence is the ratio of non-bankfinanced transactions to all financed transactions in a county as of 2008 Q1 and reported in Equifax. Column (2) defines non-bank dependence similarly, but taken over all of 2006. Column (3) defines non-bank dependence as the ratio of non-bank-financed transactions to all sales in the county, including self-financed transactions, as of 2008 Q1 and reported in Polk. Column (4) defines non-bank dependence as the ratio of non-bank-financed transactions to all financed transactions in a county as of 2008 Q1 and reported in Polk. Population, county area, median household income, Gini coefficient, poverty rate, African American population, and White population are taken from the American Community Survey. Employees in automobile sector and total employment are taken from the Quarterly Census of Employment and Wages (QCEW).

\begin{tabular}{|c|c|c|c|c|c|c|c|c|c|c|c|c|}
\hline & & Captive d & penden & & & & & & & & & \\
\hline & $\begin{array}{l}\text { Equifax } \\
2008 \\
\text { Q1 }\end{array}$ & $\begin{array}{l}\text { Equifax } \\
2006\end{array}$ & $\begin{array}{l}\text { Polk } \\
2008 \\
\text { Q1 }\end{array}$ & $\begin{array}{l}\text { Polk } \\
2008 \text { Q1 } \\
\text { financed }\end{array}$ & $\begin{array}{l}\text { County } \\
\text { area, log }\end{array}$ & $\begin{array}{l}\text { Population, } \\
\log \end{array}$ & $\begin{array}{l}\text { Median } \\
\text { income, } \\
\text { log }\end{array}$ & $\begin{array}{l}\text { African } \\
\text { American } \\
\text { population, } \\
\log \end{array}$ & $\begin{array}{l}\text { White } \\
\text { population, log }\end{array}$ & $\begin{array}{l}\text { Gini } \\
\text { coefficient }\end{array}$ & $\begin{array}{l}\text { Employment } \\
\text { in } \\
\text { Automobile } \\
\text { Sector, share }\end{array}$ & $\begin{array}{l}\text { Median credit } \\
\text { score, } 2008 \text { Q1 } \\
\text { (Trans union) }\end{array}$ \\
\hline \multicolumn{13}{|l|}{ Mean } \\
\hline & 0.49 & 0.45 & 0.39 & 0.52 & 6.47 & 10.25 & 0.66 & 6.78 & 10.06 & 0.43 & 0.42 & 675.74 \\
\hline \multicolumn{13}{|l|}{ Median } \\
\hline & 0.5 & 0.45 & 0.38 & 0.52 & 6.42 & 10.15 & 10.65 & 6.95 & 9.99 & 0.43 & 0 & 679 \\
\hline \multicolumn{13}{|l|}{25 th } \\
\hline $\begin{array}{l}\text { percentile } \\
75 \text { th }\end{array}$ & 0.38 & 0.35 & 0.32 & 0.44 & 6.06 & 9.32 & 10.5 & 4.9 & 9.12 & 0.41 & 0 & 634 \\
\hline percentile & 0.6 & 0.56 & 0.45 & 0.6 & 6.82 & 11.09 & 10.79 & 8.73 & 10.94 & 0.45 & 0.04 & 717 \\
\hline \multicolumn{13}{|l|}{ Min } \\
\hline & 0.1 & 0 & 0.08 & 0.14 & 0.69 & 4.39 & 9.86 & 0 & 4.17 & 0.21 & 0 & 507.5 \\
\hline \multicolumn{13}{|l|}{ Max } \\
\hline & 0.88 & 1 & 1 & 1 & 9.91 & 16.1 & 11.65 & 14.11 & 15.42 & 0.64 & 18.66 & 811 \\
\hline $\begin{array}{l}\text { Standard } \\
\text { deviation }\end{array}$ & 0.15 & 0.18 & 0.1 & 0.12 & 0.87 & 1.45 & 0.25 & 2.61 & 1.44 & 0.04 & 1.44 & 54.66 \\
\hline
\end{tabular}




\section{TABLE II}

THE DETERMINANTS OF NON-BANK DEPENDENCE

This table reports the regression results of regressing county-level non-bank dependence (Polk), 2008 Q1, on demographic and economic variables observed around the same period. Employment in the automobile sector is number of employees in the automobile sector divided by total employment. The socioeconomic variables are taken from the American Community Survey. County-level unemployment rates come from the Bureau of Labor Statistics. Employees in automobile sector are taken from the Quarterly Census of Employment and Wages (QCEW). The dependent variable in column (14) is non-bank-financed to all transactions (Polk).

\begin{tabular}{|c|c|c|c|c|c|c|c|c|c|c|c|}
\hline & & & & Dependent va & ble: non-bank & ed to all fina & ed transac & ns (Polk) & & & \\
\hline & (1) & (2) & (3) & (4) & (5) & (6) & (7) & (8) & (9) & (10) & (11) \\
\hline \multirow[t]{2}{*}{ County area, log } & -0.00419 & & & & & & & & & & \\
\hline & $(0.00364)$ & & & & & & & & & & \\
\hline \multirow[t]{3}{*}{ Population, log } & & $0.0104 * *$ & & & & & & & & & \\
\hline & & $*$ & & & & & & & & & \\
\hline & & $(0.00289)$ & & & & & & & & & \\
\hline \multirow[t]{2}{*}{ Median income, log } & & & $0.0396 * *$ & & & & & & & & \\
\hline & & & $(0.0153)$ & & & & & & & & \\
\hline \multirow[t]{2}{*}{ African American population, log } & & & & $0.00795 * * *$ & & & & & & & \\
\hline & & & & $(0.00173)$ & & & & & & & \\
\hline \multirow[t]{2}{*}{ White population, log } & & & & & $0.00843^{* * *}$ & & & & & & \\
\hline & & & & & $(0.00288)$ & & & & & & \\
\hline \multirow[t]{2}{*}{ Gini Coefficient } & & & & & & $0.325 * * *$ & & & & & \\
\hline & & & & & & $(0.0853)$ & & & & & \\
\hline \multirow{2}{*}{$\begin{array}{l}\text { Employment in automobile sector, } \\
\text { share }\end{array}$} & & & & & & & -0.0461 & & & & \\
\hline & & & & & & & $(0.160)$ & & & & \\
\hline Median credit score, 2008 Q1 (Trans & & & & & & & & -0.000137 & & & \\
\hline \multicolumn{12}{|l|}{ Union) } \\
\hline & & & & & & & & (9.60e-05) & & & \\
\hline \multirow[t]{2}{*}{ Unemployment rate, 2008} & & & & & & & & & 0.000758 & & \\
\hline & & & & & & & & & $(0.00136)$ & & \\
\hline Unemployment rate, 2006 & & & & & & & & & & -0.00150 & \\
\hline
\end{tabular}


(0.00336)

Unemployment rate, 2007

$-0.000543$

(0.00299)

Poverty rate, 2008

Change in house prices, 2005-2006

\begin{tabular}{|c|c|c|c|c|c|c|c|c|c|c|c|}
\hline Observations & 3,092 & 3,092 & 3,092 & 2,860 & 3,092 & 3,092 & 3,087 & 3,092 & 2,534 & 2,534 & 2,534 \\
\hline R-squared & 0.309 & 0.320 & 0.313 & 0.371 & 0.316 & 0.316 & 0.308 & 0.310 & 0.299 & 0.299 & 0.299 \\
\hline
\end{tabular}


Table II Cont'd. The Determinants of Non-Bank Dependence

\begin{tabular}{|c|c|c|c|c|}
\hline & \multicolumn{3}{|c|}{ Dependent variable: non-bank financed to all financed transactions, (Polk) } & \multirow{2}{*}{$\begin{array}{l}\text { Dependent variable: non-bank } \\
\text { financed to all transactions, (Polk) } \\
\text { (15) }\end{array}$} \\
\hline & $(12)$ & (13) & (14) & \\
\hline \multirow[t]{2}{*}{ County area, log } & & & -0.00391 & 0.00354 \\
\hline & & & $(0.00614)$ & $(0.00471)$ \\
\hline \multirow[t]{2}{*}{ Population, log } & & & $0.0443^{*}$ & 0.0146 \\
\hline & & & $(0.0244)$ & $(0.0231)$ \\
\hline \multirow[t]{2}{*}{ Median income, log } & & & $0.0425 * *$ & $0.0684 * * *$ \\
\hline & & & $(0.0173)$ & $(0.0158)$ \\
\hline \multirow[t]{2}{*}{ African American population, log } & & & 0.00185 & 0.000138 \\
\hline & & & (0.00248) & $(0.00227)$ \\
\hline \multirow[t]{2}{*}{ White population, log } & & & $-0.0418^{*}$ & -0.00936 \\
\hline & & & $(0.0226)$ & $(0.0216)$ \\
\hline \multirow[t]{2}{*}{ Gini coefficient } & & & $0.300 * * *$ & 0.101 \\
\hline & & & $(0.0788)$ & $(0.0625)$ \\
\hline \multirow[t]{2}{*}{ Employment in automobile, share } & & & -0.105 & $-0.211^{*}$ \\
\hline & & & $(0.145)$ & $(0.114)$ \\
\hline \multirow[t]{2}{*}{ Median credit score, 2008 Q1 (Trans Union) } & & & $-4.06 e-05$ & $-0.000692 * * *$ \\
\hline & & & $(0.000103)$ & $(9.18 \mathrm{e}-05)$ \\
\hline \multirow[t]{2}{*}{ Unemployment rate, 2008} & & & -0.000244 & 0.00128 \\
\hline & & & $(0.00110)$ & $(0.000891)$ \\
\hline \multicolumn{5}{|l|}{ Unemployment rate, 2006} \\
\hline \multicolumn{5}{|l|}{ Unemployment rate, 2007} \\
\hline \multirow[t]{2}{*}{ Poverty rate, 2008} & 0.000616 & & & \\
\hline & $(0.000710)$ & & & \\
\hline \multirow[t]{2}{*}{ Change in house prices, 2005-2006 } & & -0.0913 & & \\
\hline & & $(0.0897)$ & & \\
\hline Observations & 3,092 & 1,239 & 2,301 & 2,301 \\
\hline
\end{tabular}




\section{TABLE III}

\section{NON-BANK DEPENDENCE AND NON-BANK SALES}

This table reports the regression results of estimating Eq. (1). The dependent variable is the log change in the number of cars financed by nonbanks in 2009 relative to 2008 as reported in Polk. Non-bank dependence is the ratio of non-bank financed to all financed transactions, (Polk) 2008:Q1. Percentage African American is the African American population divided by population. Employment in automobile sector is number of employees in the automobile sector divided by total employment. Population, county area, median household income, Gini coefficient, poverty rate, African American population, and White population are taken from the American Community Survey. County-level unemployment rates are taken from the BLS. Employees in automobile sector and total employment are taken from the Quarterly Census of Employment and Wages (QCEW). Household leverage is the debt-to-income ratio (Federal Reserve Bank of New York). House price change is the change in the house price index (CoreLogic). Household net-worth is from Mian and Sufi (forthcoming). All variables are defined in Appendix A. All regressions are weighted by the county population and include state fixed effects, except for column 1 . Standard errors are clustered at the state level. ***, **,* denotes significance at the $1 \%, 5 \%$, and $10 \%$ levels, respectively.

\begin{tabular}{|c|c|c|c|c|c|}
\hline VARIABLES & $\begin{array}{l}\text { Economic and } \\
\text { demographic } \\
\text { controls, without } \\
\text { state fixed effects }\end{array}$ & $\begin{array}{l}\text { Economic and } \\
\text { demographic controls, } \\
\text { with state fixed effects }\end{array}$ & $\begin{array}{l}\text { Unemployment } \\
\text { and leverage }\end{array}$ & House prices & $\begin{array}{l}\text { Household net } \\
\text { worth }\end{array}$ \\
\hline & (1) & $(2)$ & (3) & (4) & (5) \\
\hline \multirow{4}{*}{$\begin{array}{l}\text { Captive dependence, } 2008 \\
\text { Q1 (Polk), financed } \\
\text { transactions }\end{array}$} & $-0.369 * *$ & $-0.319 * * *$ & $-0.342^{* * *}$ & $-0.348 * * *$ & $-0.316 * * *$ \\
\hline & & & & & \\
\hline & & & & & \\
\hline & $(0.141)$ & $(0.0620)$ & $(0.0679)$ & $(0.0811)$ & $(0.0771)$ \\
\hline \multirow[t]{2}{*}{ County area, log } & $-0.0656 * *$ & $-0.0227 * *$ & $-0.0243 * *$ & $-0.0270^{*}$ & $-0.0271^{*}$ \\
\hline & $(0.0289)$ & $(0.0112)$ & $(0.0119)$ & $(0.0140)$ & $(0.0141)$ \\
\hline \multirow[t]{2}{*}{ population, log } & 0.109 & $0.108^{* * *}$ & $0.107^{* * *}$ & $0.110^{* * *}$ & $0.102^{* * *}$ \\
\hline & $(0.0706)$ & $(0.0336)$ & $(0.0345)$ & $(0.0373)$ & $(0.0361)$ \\
\hline \multirow[t]{2}{*}{ Median income, log } & -0.0445 & 0.0284 & 0.0255 & 0.0389 & 0.0533 \\
\hline & $(0.0773)$ & $(0.0344)$ & $(0.0347)$ & $(0.0434)$ & $(0.0428)$ \\
\hline \multirow{3}{*}{$\begin{array}{l}\text { African American } \\
\text { population, log }\end{array}$} & -0.00390 & $0.00769 *$ & $0.00792 *$ & 0.00586 & 0.00610 \\
\hline & & & & & \\
\hline & $(0.0104)$ & $(0.00403)$ & (0.00439) & $(0.00518)$ & $(0.00492)$ \\
\hline \multirow[t]{2}{*}{ White population, log } & -0.0662 & $-0.110 * * *$ & $-0.110 * * *$ & $-0.106 * * *$ & $-0.0973 * * *$ \\
\hline & $(0.0606)$ & $(0.0286)$ & $(0.0301)$ & $(0.0315)$ & $(0.0310)$ \\
\hline \multirow[t]{2}{*}{ Gini coefficient } & 0.519 & $0.365 * *$ & $0.407^{* *}$ & $0.354^{*}$ & 0.272 \\
\hline & $(0.348)$ & $(0.174)$ & $(0.165)$ & $(0.183)$ & $(0.201)$ \\
\hline \multirow{2}{*}{$\begin{array}{l}\text { Employment in } \\
\text { automobile, share }\end{array}$} & -1.136 & -0.274 & -0.303 & -0.323 & -0.396 \\
\hline & $(0.837)$ & $(0.261)$ & $(0.254)$ & $(0.335)$ & $(0.353)$ \\
\hline Median credit score, 2008 & & $0.000881^{* * *}$ & $0.000851 * * *$ & $0.000809 * * *$ & $0.000842 * * *$ \\
\hline \multirow[t]{2}{*}{ Q1 (Trans Union) } & $0.00103 * *$ & & & & \\
\hline & $(0.000450)$ & $(0.000174)$ & $(0.000184)$ & $(0.000236)$ & $(0.000238)$ \\
\hline \multirow[t]{2}{*}{ House price change } & & & & 0.0812 & \\
\hline & & & & $(0.125)$ & \\
\hline \multirow[t]{2}{*}{ Unemployment rate } & & & 0.00492 & 0.00363 & \\
\hline & & & $(0.00438)$ & $(0.00420)$ & \\
\hline
\end{tabular}


Household leverage, 2006

Change in household net

worth, 2006-2009
2,825

0.236
0.0227

(0.0231)

R-squared

2,825

0.785

958

0.840

(0.0912)

932

0.842 


\section{TABLE IV}

\section{NON-BANK DEPENDENCE AND AGgREGATE EFFECTS}

This table reports regression results of estimating Eq. (1). The dependent variable in column (1) is the log change in the number of cars financed by banks and credit unions in 2009 relative to 2008 . The dependent variable in columns (2)-(6) is the log change in the total number cars sold in a county in 2009 relative to 2008 , regardless of the source of financing. Column (7) uses the log change in total number cars sold in a county in 2009 relative to 2007, regardless of the source of financing, as the dependent variable. Column (3) defines non-bank dependence as the ratio of non-bank transactions to all financed transactions, based on data from Equifax in 2006. Column (4) defines non-bank dependence as the ratio of non-bank transactions to all financed transactions, based on data from Equifax in 2008 Q1. Column (5) defines non-bank dependence as the ratio of non-bank transactions to all transactions, based on data from Equifax in 2006.

Column (6) adds the Equifax measure of median credit score in the county of buyers using non-bank sources of automotive credit, observed in 2008 Q1, to the set of control variables. All columns include the same set of controls as in column (2) of Table III. All variables are defined in Appendix A. All regressions are weighted by the county population and include state fixed effects. Standard errors are clustered at the state level. ***, **, * denotes significance at the $1 \%, 5 \%$, and $10 \%$ levels, respectively.

\begin{tabular}{|c|c|c|c|c|c|c|c|}
\hline & \multirow{2}{*}{$\begin{array}{l}\text { Bank-financed } \\
\text { transactions }\end{array}$} & \multicolumn{6}{|c|}{ All transactions } \\
\hline & & (2) & (3) & (4) & (5) & (6) & (7) \\
\hline VARIABLES & $\begin{array}{l}\text { Non-bank } \\
\text { dependence: Polk, } \\
2006\end{array}$ & $\begin{array}{l}\text { Non-bank } \\
\text { dependence: Polk, } \\
2006\end{array}$ & $\begin{array}{l}\text { Non-bank } \\
\text { dependence: } \\
\text { Equifax, } 2006\end{array}$ & $\begin{array}{l}\text { Non-bank } \\
\text { dependence: } \\
\text { Equifax, } 2008\end{array}$ & $\begin{array}{l}\text { Polk: Extensive } \\
\text { margin }\end{array}$ & Equifax credit score & Change: 2009-2007 \\
\hline \multirow[t]{2}{*}{$\begin{array}{l}\text { Non-bank dependence, } \\
2008 \text { Q1 (Polk), financed } \\
\text { transactions }\end{array}$} & $0.257^{* * *}$ & $-0.0926^{*}$ & & & & $-0.0940^{*}$ & $-0.121^{*}$ \\
\hline & $(0.0831)$ & $(0.0490)$ & & & & $(0.0503)$ & $(0.0660)$ \\
\hline $\begin{array}{l}\text { Non-bank dependence, } \\
\text { Equifax, 2006, financed } \\
\text { transactions }\end{array}$ & & & $-0.117^{* * *}$ & & & & \\
\hline & & & $(0.0251)$ & & & & \\
\hline $\begin{array}{l}\text { Non-bank dependence, } \\
\text { Equifax, 2008, Q1, } \\
\text { financed transactions }\end{array}$ & & & & $-0.0972 * * *$ & & & \\
\hline
\end{tabular}


(0.0220)

Non-bank dependence,

margin

median credit score, 2008

Q1 (Equifax, non-banks)

\section{Q1 (Polk), extensive}

$-0.126^{* *}$

(0.0567)

$5.12 \mathrm{e}-05$

Observations

$2,825 \quad 2,825$

0.700
2,827

0.707
2,287

0.723
2,825

0.705
2,825

0.797 
TABLE V

Within-MAKe EFFECTS OF CAPTIVE FINANCING ON AUTO SALES

The dependent variable in column (1) is the log change in all GM sales in 2009 relative to 2008. Column (2) is the log change in GMAC-financed GM sales. Column (3) is the log change in all non-GMAC financed GM sales. Columns (4)-(9) follow a similar pattern for Ford and Toyota sales. Captive dependence is defined as the 2008 Q1 market shares of GMAC, FMC, and TMC, respectively, in a particular county. In all cases, the share of the make in total county sales is included as a regressor along with the demographic controls in column (2) of Table III. All changes are defined as the percentage change in 2009 over 2008. Column (10) stacks the data by make: GM, Ford, Toyota and Honda; county and model segment. Column (10) includes county and brand fixed effects, along with county-segment fixed effects. All regressions are weighted by the county population and include state fixed effects. Standard errors are clustered at the state level. $* * *, * *, *$ denotes significance at the $1 \%, 5 \%$, and $10 \%$ levels, respectively.

\begin{tabular}{|c|c|c|c|c|c|c|c|c|c|c|}
\hline & All GM & GMAC & Substitution: & All Ford & FMC & Substitution: & All & TMC & Substitution: & County, \\
\hline & Sales & Financed & Non-GMAC & Sales & Financed & Non-FMC & Toyota & Financed & Non-TMC & Make- \\
\hline & & GM & financed & & Ford Sales & financed & Sales & Toyota & Financed & Segment \\
\hline & & Sales & GM sales & & & Ford sales & & Sales & Toyota Sales & fixed \\
\hline & & & & & & & & & & effects \\
\hline Variables & (1) & (2) & (3) & (4) & (5) & (6) & (7) & (8) & (9) & (10) \\
\hline \multirow{2}{*}{$\begin{array}{l}\text { Non-bank } \\
\text { dependence }\end{array}$} & $-0.0419 *$ & $-0.425 * * *$ & $0.0814 * * *$ & $-0.0371 * *$ & $-0.146 * * *$ & $0.299 * * *$ & $-0.0202 *$ & $-0.233 * * *$ & $0.192 * * *$ & $-0.0262 *$ \\
\hline & $(0.0228)$ & $(0.0537)$ & $(0.0288)$ & $(0.0182)$ & $(0.0266)$ & $(0.0295)$ & $(0.0117)$ & $(0.0613)$ & $(0.0264)$ & $(0.0145)$ \\
\hline Observations & 2,857 & 2,854 & 2,857 & 2,857 & 2,856 & 2,856 & 2,855 & 2,837 & 2,851 & 32,872 \\
\hline R-squared & 0.377 & 0.407 & 0.509 & 0.389 & 0.369 & 0.583 & 0.289 & 0.328 & 0.271 & 0.718 \\
\hline
\end{tabular}




\section{TABLE VI}

\section{NON-BANK DEPENDENCE AND INDIVIDUAL-LEVEL CHARACTERISTICS, EQUIFAX}

This table reports summary statistics from the Equifax data set in 2007 at the county level. Panel A restricts the sample to individuals living in counties with a below median "captive dependence" share, defined as the ratio of captive financed transactions to all retail transactions, as recorded in Polk 2008 Q1. Panel B restricts the sample to those counties at or above the median level of captive dependence. Credit card balances are computed for the sample of individuals with a positive balance.

\begin{tabular}{|c|c|c|c|c|c|}
\hline & Credit card balance & Credit card limits & FICO score & Year of birth & Homeownership rate \\
\hline & \multicolumn{5}{|c|}{ A. Counties below the median in "captive dependence" } \\
\hline Mean & 5,232 & $3,992.3$ & 687.3 & 1957.4 & 0.18 \\
\hline Median & 4,301 & $3,774.3$ & 690.4 & 1957.7 & 0.18 \\
\hline Standard & 5,282 & $1,707.2$ & 27.2 & 3.0 & 0.07 \\
\hline & \multicolumn{5}{|c|}{ B. Counties above the median in "captive dependence" } \\
\hline Mean & 5,594 & $3,439.5$ & 674.2 & 1958.4 & 0.17 \\
\hline Median & 4,684 & $3,201.1$ & 676.0 & 1958.6 & 0.17 \\
\hline Standard & 4,772 & $1,980.1$ & 29.4 & 3.0 & 0.07 \\
\hline Deviation & & & & & \\
\hline
\end{tabular}




\section{TABLE VII}

\section{Non-BANK DePENDENCE AND CAR BUying, INDIVIDUAL-LEVEL EVIDENCE}

The dependent variable in columns (1) and (2) equals 1 if an individual financed a car purchase in the quarter through a non-bank lender and 0 otherwise. The dependent variable in column (3) equals 1 if an individual financed a car in the quarter, regardless of the credit source and 0 otherwise. The dependent variable in column (4) equals 1 if the individual obtained a mortgage in the quarter and 0 otherwise. The dependent variable in column (4) is the $\log$ of the individual's credit limit. In all columns, the data are quarterly and, for columns (1) and (3)-(5), are observed from 2008 Q1-2009 Q4; column (2) includes data from 2007 Q1-2009 Q4.

\begin{tabular}{|c|c|c|c|c|c|}
\hline & (1) & (2) & (3) & (4) & (5) \\
\hline & Non-banks & Non-banks & All sales & Mortgage credit & Credit limit \\
\hline Variables & $2008-2009$ & $2007-2009$ & $2008-2009$ & 2008-2009 & $2008-2009$ \\
\hline \multirow[t]{2}{*}{ FICO score, $\log$} & $-0.0159 * * *$ & $-0.0188^{* * *}$ & $-0.0107 * * *$ & $0.383 * * *$ & $5.161 * * *$ \\
\hline & $(0.000873)$ & $(0.000954)$ & $(0.000743)$ & $(0.0147)$ & $(0.240)$ \\
\hline \multirow[t]{2}{*}{ Credit card balance, log } & $-0.000329 * * *$ & $-0.000358 * * *$ & $-0.000838 * * *$ & $0.00524 * * *$ & $0.923 * * *$ \\
\hline & $(4.21 \mathrm{e}-05)$ & $(3.66 \mathrm{e}-05)$ & $(7.72 \mathrm{e}-05)$ & $(0.00124)$ & $(0.00328)$ \\
\hline \multirow[t]{2}{*}{ Credit card limit, log } & $0.000308 * * *$ & $0.000335^{* * *}$ & $0.000872 * * *$ & $0.0277 * * *$ & \\
\hline & $(1.68 \mathrm{e}-05)$ & $(1.69 \mathrm{e}-05)$ & $(3.81 \mathrm{e}-05)$ & $(0.000713)$ & \\
\hline \multirow[t]{2}{*}{ Age } & $0.149 * * *$ & $0.165^{* * *}$ & $0.438 * * *$ & $3.854 * * *$ & $-46.41 * * *$ \\
\hline & $(0.0121)$ & $(0.0127)$ & $(0.0174)$ & $(0.382)$ & $(1.660)$ \\
\hline \multirow[t]{2}{*}{ Homeowner indicator } & $0.00702 * * *$ & $0.00778 * * *$ & $0.0162 * * *$ & & $2.119 * * *$ \\
\hline & $(0.000288)$ & $(0.000318)$ & $(0.000649)$ & & $(0.0545)$ \\
\hline \multirow[t]{2}{*}{ Non-bank dependence (Polk) } & $0.00818 * * *$ & $0.00787 * * *$ & $-0.00803^{*}$ & -0.0112 & $-1.535 * * *$ \\
\hline & $(0.00190)$ & $(0.00244)$ & $(0.00415)$ & $(0.0284)$ & $(0.191)$ \\
\hline \multirow[t]{2}{*}{ Non-bank dependence (Polk)* 2007 Q2 } & & $3.41 \mathrm{e}-05$ & & & \\
\hline & & $(0.000759)$ & & & \\
\hline \multirow[t]{2}{*}{ Non-bank dependence (Polk)* 2007 Q3 } & & 0.00133 & & & \\
\hline & & $(0.00260)$ & & & \\
\hline \multirow[t]{2}{*}{ Non-bank dependence (Polk)* 2007 Q4 } & & -0.00138 & & & \\
\hline & & $(0.00221)$ & & & \\
\hline \multirow[t]{2}{*}{ Non-bank dependence (Polk)* 2008 Q1 } & & -0.000629 & & & \\
\hline & & $(0.00104)$ & & & \\
\hline \multirow[t]{2}{*}{ Non-bank dependence (Polk)* 2008 Q2 } & $-0.00161 * *$ & $-0.00224 * *$ & $-0.00556 * * *$ & -0.00108 & $-0.0757 * * *$ \\
\hline & $(0.000653)$ & $(0.00103)$ & $(0.00170)$ & $(0.00230)$ & $(0.0175)$ \\
\hline \multirow[t]{2}{*}{ Non-bank dependence (Polk)* 2008 Q3 } & -0.000939 & -0.00158 & $-0.00371 * * *$ & -0.00281 & -0.00740 \\
\hline & $(0.000685)$ & $(0.00117)$ & $(0.00125)$ & $(0.00245)$ & $(0.0417)$ \\
\hline \multirow[t]{2}{*}{ Non-bank dependence (Polk)* 2008 Q4 } & $-0.00217 * *$ & $-0.00282^{*}$ & -0.00212 & -0.000755 & 0.0619 \\
\hline & $(0.000983)$ & $(0.00157)$ & $(0.00188)$ & $(0.00270)$ & $(0.0630)$ \\
\hline Non-bank dependence (Polk)* 2009 Q1 & -0.000795 & -0.00148 & 0.00162 & 0.00173 & $0.223 * * *$ \\
\hline
\end{tabular}




\begin{tabular}{llllll} 
& $(0.00127)$ & $(0.00174)$ & $(0.00192)$ & $(0.00531)$ & $(0.0789)$ \\
Non-bank dependence (Polk)* 2009 Q2 & -0.00147 & -0.00216 & -0.00251 & 0.000728 & $0.243 * * *$ \\
& $(0.00127)$ & $(0.00165)$ & $(0.00224)$ & $(0.00575)$ & $(0.0843)$ \\
Non-bank dependence (Polk)* 2009 Q3 & $-0.00664 * * *$ & $-0.00733 * * *$ & $-0.00998^{* * *}$ & -0.000442 & $0.229 * *$ \\
& $(0.00180)$ & $(0.00234)$ & $(0.00320)$ & $(0.00500)$ & $(0.0902)$ \\
Non-bank dependence (Polk)* 2009 Q4 & -0.00250 & -0.00318 & -0.00251 & -0.00175 & $0.226 * * *$ \\
Observations & $(0.00161)$ & $(0.00216)$ & $(0.00266)$ & $(0.00624)$ & $(0.0820)$ \\
R-squared & $23,665,802$ & $35,561,957$ & $23,665,802$ & $23,665,802$ & $23,665,802$ \\
\hline
\end{tabular}

\section{TABLE VIII}

\section{CAPTIVE DEPENDENCE AND CAR BUying STRATIFED by FICO SCORE}

The dependent variable equals 1 if an individual financed a car purchase in the quarter through a non-bank and 0 otherwise. All columns include the same controls as in Table VII; observed from 2008 Q1-2009 Q4, and standard errors are clustered at the state level. Column (1) includes individuals with a FICO score below 603; column (2) uses scores between 603 and 706 (second quartile); column (3) uses 706-784 (third quartile); and column (4) focuses on individuals with scores above 784 .

\begin{tabular}{lllll}
\hline Variables & Quartile 1 & Quartile 2 & Quartile 3 & Quartile 4 \\
\hline Captive dependence (Polk) & 0.00290 & $0.0129 * * *$ & $0.00980^{* * *}$ & $0.00739^{* * *}$ \\
& $(0.00378)$ & $(0.00223)$ & $(0.00144)$ & $(0.00210)$ \\
Captive dependence (Polk)* 2008 Q2 & -0.00214 & -0.00184 & $5.59 \mathrm{e}-06$ & -0.00244 \\
& $(0.00272)$ & $(0.00166)$ & $(0.00128)$ & $(0.00194)$ \\
Captive dependence (Polk)* 2008 Q3 & -0.00252 & -0.000426 & -0.000534 & 0.000776 \\
& $(0.00232)$ & $(0.00146)$ & $(0.00113)$ & $(0.000887)$ \\
Captive dependence (Polk)* 2008 Q4 & -0.00175 & -0.000221 & $-0.00261 * *$ & $-0.00254 * *$ \\
& $(0.00251)$ & $(0.00159)$ & $(0.00127)$ & $(0.00118)$ \\
Captive dependence (Polk)* 2009 Q1 & 0.000400 & -0.000336 & -0.000574 & -0.000840 \\
Captive dependence (Polk)*2009 Q2 & $(0.00270)$ & $(0.00173)$ & $(0.00138)$ & $(0.00113)$ \\
& 0.000407 & -0.000803 & -0.000461 & $-0.00287 *$ \\
Captive dependence (Polk)* 2009 Q3 & $(0.00332)$ & $(0.00184)$ & $(0.00105)$ & $(0.00154)$ \\
& $-0.00557 * *$ & $-0.00847 * * *$ & $-0.00576 * * *$ & $-0.00342 *$ \\
Captive dependence (Polk)*2009 Q4 & $(0.00269)$ & $(0.00273)$ & $(0.00199)$ & $(0.00178)$ \\
& -0.00208 & -0.00308 & -0.000748 & -0.00140 \\
\hline Observations & $(0.00328)$ & $(0.00188)$ & $(0.00174)$ & $(0.00146)$ \\
\hline R-squared & $5,870,586$ & $5,934,242$ & $5,896,749$ & $5,858,620$ \\
\hline & 0.002 & 0.003 & 0.003 & 0.003 \\
\hline
\end{tabular}




\section{Online Appendix for}

The Real Effects of Liquidity during the Financial Crisis: Evidence from Automobiles

Efraim Benmelech Ralf R. Meisenzahl RodneyRamcharan Northwestern University Federal Reserve Board USC and NBER 


\section{Appendix 1. Financial Constraints at Captives: Some Narrative Evidence}

In this section, we present narratives from the Form 10-Ks of the largest publicly traded dealership companies in the United States based on our reading of these 10Ks from 2006 to 2011. We collect and reproduce here those discussions that pertain to the role of captive leasing in the automotive industry in general and during the financial crisis in particular.

\section{AutoNation}

By the end of 2006, AutoNation was the largest automotive retailer in the United States, owning and operating 331 new vehicle franchises out of 257 stores located in major metropolitan markets. AutoNation stores sold 37 brands of new vehicles, primarily those manufactured by Ford, General Motors, DaimlerChrysler, Toyota, Nissan, Honda, and BMW. According to AutoNation's 2006 10K, the firm retailed approximately 600,000 new and used vehicles through their stores.

In 2006, AutoNation relied heavily on floorplan borrowing from captive lessors, with a total vehicle floorplan payable of $\$ 2,264.9$ million, accounting for $74.7 \%$ of the company's current liabilities and $46.3 \%$ of its total liabilities. Similarly, in 2007, total vehicle floorplan was $\$ 2,181.8$ million, accounting for $75.2 \%$ of current liabilities and $43.6 \%$ of total liabilities. Indeed, the importance of financing supplied by captive lessors for AutoNation as well as for its customers is echoed in its 2009 Form 10-K:

We obtain a significant amount of financing for our customers through the captive finance companies of automotive manufacturers, which companies were adversely impacted by the turbulence in the capital markets as well as the overall economic conditions in the United States. These conditions also adversely impacted other finance companies, including GMAC, which received extensive federal support and is now majority-owned by the U.S. Treasury. In 2009, the availability of automotive loans and leases through many of these finance companies declined significantly, forcing us to seek, at times unsuccessfully, alternative financing sources for our customers. We also rely on the captive finance companies of automotive manufacturers for floorplan financing to purchase new vehicle inventory. In 2009, many of these captive 
finance companies altered their floorplan financing programs to our detriment, providing additional restrictions on lending and increasing interest rates. ${ }^{1}$

\section{Lithia Motors}

Another large auto dealership company that is highly dependent on floorplan financing from captive lessors is Lithia Motors, a NYSE publicly listed company. Operating in both new and used vehicles markets, in 2006 Lithia Motors offered 30 brands of new vehicles through 193 franchises in the western United States, with DaimlerChrysler, General Motors, Toyota, and Ford accounting for 41.0\%, 19.4\%, 10.9\% and 7.3\% of new vehicle sales, respectively. In its Form 10-K for the fiscal year ending in December 31, 2008, the company reports:

During 2008, overall macroeconomic issues have reduced consumers' desire and ability to purchase automobiles. An additional factor negatively impacting auto sales has been a reduction in available options for consumer auto loans. The manufacturers' captive financing companies have suffered additional pressure as the financial crisis has raised their cost of funds and reduced their access to capital. This and financial stress on manufacturers has prevented them from offering as many incentives designed to drive sales, such as subsidized interest rates and the amount of loan to value they are willing to advance on vehicles. ${ }^{2}$

The tightening of the credit markets experienced in 2008 reduced the number of loans originated, restricted loans to more credit-worthy customers, reduced vehicle leasing programs and increased the overall cost of financing. ${ }^{3}$

Lithia Motors again expresses concerns about tightening credit markets and their effects on both dealerships and customers in its 2009 annual report:

\footnotetext{
${ }^{1}$ AutoNation Form 10-K for the fiscal year ending December 31, 2009, pp. 22-23.

${ }^{2}$ Lithia Motors Form 10-K for the fiscal year ending December 31, 2008, p. 4.

${ }^{3}$ Lithia Motors Form 10-K for the fiscal year ending December 31, 2008, p. 11.
} 
Credit markets continued to remain tight in 2009. . . . These constraints in financing resulted in fewer consumers in the market and less floor traffic at our stores. The financial crisis has increased the cost of funds and reduced the access to capital for finance companies (including manufacturers' captive finance companies). ${ }^{4}$

A lack of available credit continued to prove challenging to prospective purchasers of our stores. One of the primary problems was the lack of vehicle inventory floorplan financing, which is a basic requirement of the franchise agreement. Even for prospective purchasers with existing floorplan financing, obtaining mortgage financing on dealership real estate or committing to other significant capital investment proved exceedingly difficult. ${ }^{5}$

As these reports reveal, access to finance was a major concern in the U.S. auto market in 2008 and 2009. Lack of financing posed a problem not only to consumers but also to large publicly traded firms that relied heavily on floorplan financing from auto manufacturers' leasing companies. This widespread lack of credit was also listed as a key motivation for federal support of the automobile sector. ${ }^{6}$

\footnotetext{
${ }^{4}$ Lithia Motors Form 10-K for the fiscal year ending December 31, 2009, p. 7.

${ }^{5}$ Lithia Motors Form 10-K for the fiscal year ending December 31, 2009, p. 126.

${ }^{6}$ In directly supporting GM and Chrysler, guaranteeing their new car warranties, and providing credit lines to downstream industry suppliers, the Automotive Industry Financing Program under TARP noted that "the recession has made credit less available, which may have limited the ability of auto manufacturers and suppliers to finance their businesses, consumers to purchase cars, and dealers to obtain loans to sustain their inventories." http://www.gao.gov/assets/290/288835.pdf, p. 8.
} 


\section{Appendix 2. Tables and Figures}

Table A.1. Market Share of the Financial Intermediaries in the Supply of Consumer Credit

This table lists the market share of various sources of consumer credit before, during, and after the financial crisis. Panel A reports the market shares for total installment credit. Panel B reports the market share for the subset of auto loans. Consumer credit data are taken from the Financial Accounts of the United States (Flow of Funds).

\section{A. Total consumer installment credit (\%)}

\begin{tabular}{lccc|ccc}
\hline & \multicolumn{3}{c|}{ By holder } & \multicolumn{3}{c}{ By originator } \\
& 2005 & 2009 & 2010 & 2005 & 2009 & 2010 \\
\hline Credit unions & 13.9 & 12.9 & 12.2 & 13.9 & 12.9 & 12.2 \\
Commercial banks & 27.4 & 31.4 & 33.2 & 28.3 & 32.1 & 33.2 \\
Finance companies & 47.8 & 45.2 & 38.1 & 41.8 & 37.9 & 35.5 \\
\hline
\end{tabular}

\section{B. Auto loan market share (\%)}

\begin{tabular}{lccc}
\hline & 2005 & 2009 & 2010 \\
\hline Credit unions & 20.8 & 23.6 & 24.1 \\
Commercial banks & 24.1 & 32.6 & 37.0 \\
Finance companies & 51.3 & 41.3 & 36.7 \\
\hline
\end{tabular}


Table A.2. Captive-Financed Transactions, as a Share of All Non-Bank-Financed

\section{Transactions, the Big Four U.S. Automakers}

For the four largest US automakers-Chrysler, Ford, General Motors (GM) and Toyota-this table lists the percent of non-bank transactions (transactions excluding banks and credit unions) financed by the captive arm of these automakers in 2008.

\begin{tabular}{|l|l|l|}
\hline Brand & Captive financing arm & $\begin{array}{l}\text { Captive } \\
\text { financed } \\
\text { transactions } \\
(\%)\end{array}$ \\
\hline Chrysler & Chrysler Financial & 86.1 \\
\hline Dodge & Chrysler Financial & 84.1 \\
\hline Ford & Ford Motor Credit Company & 73.7 \\
\hline Cadillac (GM) & GMAC Financial Services & 97.8 \\
\hline Buick (GM) & GMAC Financial Services & 93.9 \\
\hline Gmc (GM) & GMAC Financial Services & 90.5 \\
\hline Chevrolet (GM) & GMAC Financial Services & 98.4 \\
\hline Toyota & Toyota Financial Services & 94.2 \\
\hline
\end{tabular}




\section{Table A.3. Automobile Captives and Commercial Paper, 2005}

This table lists the percentage of commercial paper in all liabilities (bank loans, notes, bonds, and debentures, debt due to parent firm, and other liabilities excluding equity and retained earnings) in 2005 for four major automobile captives operating in the United States. The data are supervisory and non-public.

\begin{tabular}{lrrrr}
\hline Captive & 1 & 2 & 3 & 4 \\
Share of commercial paper & 66.67 & 45.91 & 10.23 & 75.12
\end{tabular}




\section{Table A.4. Summary Statistics of County-Level Retail Sales}

This table presents the summary statistics for retail car sales across all counties for each year. Retail sales are the sum of retail purchases and retail leases in Polk. The sample period is 2002 to 2013.

\begin{tabular}{|c|c|c|c|c|c|c|c|}
\hline & & Standard & & 25th & & 75th & \\
\hline Year & Mean & deviation & Min & Percentile & Median & Percentile & Max \\
\hline 2002 & 4,210 & 14,323 & 2 & 343 & 886 & 2,464 & 420,627 \\
\hline 2003 & 4,251 & 13,945 & 1 & 340 & 868 & 2,485 & 420,561 \\
\hline 2004 & 4,173 & 14,269 & 1 & 347 & 875 & 2,508 & 443,374 \\
\hline 2005 & 4,096 & 14,343 & 2 & 331 & 845 & 2,405 & 456,466 \\
\hline 2006 & 3,996 & 14,082 & 2 & 327 & 820 & 2,360 & 443,677 \\
\hline 2007 & 3,866 & 13,331 & 1 & 321 & 808 & 2,332 & 409,445 \\
\hline 2008 & 3,168 & 10,651 & 3 & 273 & 678 & 1,931 & 314,265 \\
\hline 2009 & 2,563 & 8,334 & 2 & 219 & 528 & 1,553 & 235,562 \\
\hline 2010 & 2,771 & 9,115 & 1 & 237 & 565 & 1,664 & 259,567 \\
\hline 2011 & 3,113 & 10,045 & 3 & 280 & 667 & 1,926 & 287,269 \\
\hline 2012 & 3,553 & 11,945 & 3 & 313 & 746 & 2,191 & 367,536 \\
\hline 2013 & 3,881 & 13,342 & 3 & 329 & 795 & 2,343 & 417,487 \\
\hline
\end{tabular}




\section{Table A.5. Correlations between Measures of Non-Bank Dependence}

The dependent variable in the table is non-bank dependence defined as the ratio of non-bank-financed transactions to all financed transactions in a county in 2008 Q1 and reported in Equifax. All regressions include state fixed effects and are weighted by the population in the county; standard errors are clustered at the state level; ***,**, * denotes significance at the $1 \%, 5 \%$, and $10 \%$ levels, respectively.

\begin{tabular}{|c|c|c|c|}
\hline Variables & (1) & (2) & (3) \\
\hline \multirow{2}{*}{$\begin{array}{l}\text { Non-bank dependence, } 2006 \text { (Equifax), non- } \\
\text { bank-financed to all financed transactions }\end{array}$} & $0.815 * * *$ & & \\
\hline & $(0.0441)$ & & \\
\hline \multirow{2}{*}{$\begin{array}{l}\text { Non-bank dependence, } 2008 \text { Q1 (Polk), non- } \\
\text { bank-financed to all retail transactions }\end{array}$} & & $0.821^{* * *}$ & \\
\hline & & $(0.0778)$ & \\
\hline \multirow{2}{*}{$\begin{array}{l}\text { Non-bank dependence, } 2008 \text { Q1 (Polk), Non- } \\
\text { bank-financed to all financed transactions }\end{array}$} & & & $0.762 * * *$ \\
\hline & & & $(0.0854)$ \\
\hline Observations & 2,342 & 2,342 & 2,342 \\
\hline R-squared & 0.685 & 0.535 & 0.554 \\
\hline
\end{tabular}




\section{Table A.6. Non-Bank Dependence and Non-Bank Sales, Additional Robustness}

\section{Checks}

This table considers additional robustness checks for the results presented in Table 3 of the main text. The dependent variable is the log change in non-bank financed transactions in 2009 relative to 2008 within the county. Column 1 uses the log change in key demographic variables between 2005-2009 ACS and the 2000 census. Columns 2 and 3 include leverage and unemployment separately and column 4 considers the interaction between leverage and the change in house prices.

VARIABLES

Captive dependence, 2008 Q1 (Polk), financed transactions

County area,log

Population, $\log$

Median income, $\log$

African American population, log

White population, $\log$

Gini coefficient

Employment in automobile, share

Median credit score, 2008 Q1 (Trans Union)

Unemployment rate

Gini coefficient, change, 2009-2000

African American population, change, 2009-2000

Poverty rate, change, 2009-2000

Median income, change, 2009-2000

Household leverage, 2006

House price change

House price change* household leverage, 2006

$0.000638 * * *$
$-0.716^{*}$

(0.414)

$-0.0200 * *$

(0.00763)

0.00582

(0.0237)

0.121

(0.0842)
(1) (2)

Changes

(3)

(4)

Leverage*house price change

Leverage

$-0.345 * * *$

$-0.249 * * *$

$-0.322 * * *$

$-0.338 * * *$

(0.0815)

$0.0381 * * *$

(0.0621)

(0.0672)

-0.0261 *

(0.0117)

(0.0113)

-0.0237 *

(0.0134)

$0.0230 * * *$

$0.107 * * *$

(0.0119)

$0.106 * * *$

(0.00650)

(0.0332)

$0.109 * * *$

(0.0361)

0.0313

(0.0351)

0.0370

(0.0346)

(0.0437)

0.00749 *

0.00677

(0.00401)

(0.00442)

(0.00551)

$-0.108 * * *$

$-0.112 * * *$

$-0.104 * * *$

(0.0284)

(0.0304)

(0.0309)

$0.349 *$

$0.422 * * *$

$0.352 *$

(0.185)

(0.156)

(0.184)

$-0.281$

$-0.295$

$-0.322$

(0.261)

$0.000878^{* * * *}$

(0.255)

(0.338)

(0.000164)

(0.000177)

$0.000807 * * *$

0.00499

(0.00448)

(0.000181)

(0.000237)

0.00374

(0.00426) 
Table A.7. Non-Bank Dependence and Bank Sales, Additional Robustness Checks

This table repeats the analysis in column (1) of Table IV for each of the specifications in Table III. The dependent variable is the log change in the number of cars financed by banks and credit unions in 2009 relative to 2008. All regressions are weighted by the county population and include state fixed effects. Standard errors are clustered at the state level. $* * *, * *, *$ denotes significance at the $1 \%, 5 \%$, and $10 \%$ levels, respectively.

\begin{tabular}{|c|c|c|c|}
\hline & (1) & $(2)$ & (3) \\
\hline VARIABLES & Unemployment and leverage & House prices & Household net worth \\
\hline \multirow[t]{2}{*}{ Non-bank dependence, 2008 Q1 (Polk), financed transactions } & $0.294 * * *$ & $0.349 * *$ & $0.355^{* * *}$ \\
\hline & $(0.100)$ & $(0.134)$ & $(0.121)$ \\
\hline \multirow[t]{2}{*}{ County area,log } & 0.00674 & 0.0112 & 0.0145 \\
\hline & $(0.0157)$ & $(0.0147)$ & $(0.0154)$ \\
\hline \multirow[t]{2}{*}{ Population, log } & -0.0478 & -0.0572 & -0.0551 \\
\hline & $(0.0565)$ & $(0.0596)$ & $(0.0591)$ \\
\hline \multirow[t]{2}{*}{ Median income, log } & $-0.0998 * *$ & $-0.0882 * *$ & $-0.105^{* *}$ \\
\hline & $(0.0454)$ & $(0.0407)$ & $(0.0444)$ \\
\hline \multirow[t]{2}{*}{ African American population, $\log$} & $0.0191 * *$ & $0.0220 * * *$ & $0.0271 * * *$ \\
\hline & $(0.00739)$ & $(0.00800)$ & $(0.00890)$ \\
\hline \multirow[t]{2}{*}{ White population, log } & 0.0291 & 0.0279 & 0.0181 \\
\hline & $(0.0467)$ & $(0.0487)$ & $(0.0473)$ \\
\hline \multirow[t]{2}{*}{ Gini coefficient } & $-0.504 * *$ & $-0.404 * *$ & $-0.642 * * *$ \\
\hline & $(0.195)$ & $(0.157)$ & $(0.177)$ \\
\hline \multirow[t]{2}{*}{ Employment in automobile, share } & -0.00441 & 0.0228 & 0.00663 \\
\hline & $(0.166)$ & $(0.188)$ & $(0.210)$ \\
\hline \multirow[t]{2}{*}{ Median credit score, 2008 Q1 (Trans Union) } & $0.00140 * * *$ & $0.00104 * * *$ & $0.00111 * * *$ \\
\hline & $(0.000274)$ & $(0.000239)$ & $(0.000232)$ \\
\hline \multirow[t]{2}{*}{ House price change } & & $0.623 * * *$ & \\
\hline & & $(0.128)$ & \\
\hline \multirow[t]{2}{*}{ Unemployment rate } & -0.00164 & 0.00169 & \\
\hline & $(0.00466)$ & $(0.00483)$ & \\
\hline \multirow[t]{2}{*}{ Household leverage, 2006} & -0.0212 & -0.00470 & \\
\hline & $(0.0190)$ & $(0.0193)$ & \\
\hline \multirow[t]{2}{*}{ Change in household net worth, 2006-2009 } & & & $0.377 * * *$ \\
\hline & & & $(0.120)$ \\
\hline Observations & 2,056 & 958 & 932 \\
\hline R-squared & 0.719 & 0.790 & 0.783 \\
\hline
\end{tabular}




\section{Table A.8. Non-Bank Dependence, Money Market Flows, and Aggregate Car Sales}

The dependent variable is the quarterly log change in total car sales in a county, observed from 2006 Q1 to 2009 Q4. All regressions include the same set of controls as in Table 4 column (1). All regressions are weighted by the county population and include state fixed effects. Standard errors are clustered at the state level. ***, **, * denotes significance at the $1 \%, 5 \%$, and $10 \%$ levels.

(1)

Non-Treasury institutional flows

\begin{tabular}{ccc}
$-0.0216^{* * *}$ & $-0.0178^{* * *}$ & $-0.0236^{* * *}$ \\
$(0.00427)$ & $(0.00421)$ & $(0.00438)$ \\
$0.0263^{* * *}$ & -0.00201 & -0.00433 \\
$(0.00310)$ & $(0.00137)$ & $(0.00272)$ \\
31,170 & 31,170 & 31,170 \\
0.737 & 0.668 & 0.666 \\
\hline
\end{tabular}

(2)

(3)

Non-Treasury retail flows Non-Treasury total flows
VARIABLES

Non-bank dependence, 2008 Q1 (Polk), financed transactions

Non-bank dependence, 2008 Q1 (Polk), financed transactions*percent change in money market flows

Observations

R-squared

Robust standard errors in parentheses 


\section{Table A.9. Non-Bank Dependence and Aggregate Car Sales, by Geographic Regions}

This table replicates column (2) of Table IV using different subsamples of U.S. counties, by U.S. Census geographic regions. The dependent variable is the log change in non-bank financed transactions in 2009 relative to 2008. All regressions are weighted by the county population and include state fixed effects. Standard errors are clustered at the state level. $* * *, * * *$ denotes significance at the $1 \%, 5 \%$, and $10 \%$ levels.

\begin{tabular}{|c|c|c|c|c|}
\hline VARIABLES & $\begin{array}{l}\text { New England and Mid-Atlantic } \\
\text { states }\end{array}$ & $\begin{array}{c}\text { North Central states (East and } \\
\text { West) }\end{array}$ & $\begin{array}{l}\text { (3) } \\
\text { South and Border } \\
\text { states }\end{array}$ & $\begin{array}{l}\text { (4) } \\
\begin{array}{c}\text { Mountain and Pacific } \\
\text { states }\end{array} \\
\end{array}$ \\
\hline Non-bank dependence, 2008 Q1 (Polk), financed transactions & $\begin{array}{c}0.0457 \\
(0.0932)\end{array}$ & $\begin{array}{l}-0.0846 \\
(0.113)\end{array}$ & $\begin{array}{l}-0.128 * \\
(0.0657)\end{array}$ & $\begin{array}{l}-0.0817 \\
(0.0531)\end{array}$ \\
\hline County area, log & $\begin{array}{l}-0.000193 \\
(0.00354)\end{array}$ & $\begin{array}{c}0.00847 \\
(0.00668)\end{array}$ & $\begin{array}{l}-0.00510 \\
(0.00357)\end{array}$ & $\begin{array}{c}-0.00981 * * \\
(0.00422)\end{array}$ \\
\hline Population, log & $\begin{array}{l}-0.00216 \\
(0.0155)\end{array}$ & $\begin{array}{c}0.0510 \\
(0.0401)\end{array}$ & $\begin{array}{c}0.0716^{* * *} \\
(0.0222)\end{array}$ & $\begin{array}{c}0.0422 \\
(0.0291)\end{array}$ \\
\hline Median income, log & $\begin{array}{c}-0.0869 * * * \\
(0.0145)\end{array}$ & $\begin{array}{c}0.0412 \\
(0.0740)\end{array}$ & $\begin{array}{l}-0.0159 \\
(0.0328)\end{array}$ & $\begin{array}{l}-0.0699 * \\
(0.0339)\end{array}$ \\
\hline African American population, log & $\begin{array}{l}0.0182 * * * \\
(0.00343)\end{array}$ & $\begin{array}{c}0.00488 \\
(0.00232)\end{array}$ & $\begin{array}{l}0.00838 * \\
(0.00404)\end{array}$ & $\begin{array}{l}0.0149 * * * \\
(0.00429)\end{array}$ \\
\hline White population, $\log$ & $\begin{array}{l}-0.0145 \\
(0.0158)\end{array}$ & $\begin{array}{l}-0.0776 \\
(0.0463)\end{array}$ & $\begin{array}{c}-0.0795 * * * \\
(0.0179)\end{array}$ & $\begin{array}{c}-0.0586 * * \\
(0.0265)\end{array}$ \\
\hline Gini coefficient & $\begin{array}{c}-0.417 * * \\
(0.173)\end{array}$ & $\begin{array}{c}0.434 \\
(0.258)\end{array}$ & $\begin{array}{l}0.0609 \\
(0.134)\end{array}$ & $\begin{array}{l}-0.113 \\
(0.234)\end{array}$ \\
\hline Employment in automobile, share & $\begin{array}{l}-0.845 \\
(0.941)\end{array}$ & $\begin{array}{c}-0.530 * * \\
(0.116)\end{array}$ & $\begin{array}{c}0.335 \\
(0.210)\end{array}$ & $\begin{array}{l}0.0532 \\
(0.165)\end{array}$ \\
\hline Median credit score, 2008 Q1 (Trans Union) & $\begin{array}{l}0.00114 * * * \\
(9.70 \mathrm{e}-05)\end{array}$ & $\begin{array}{c}0.000361 \\
(0.000265)\end{array}$ & $\begin{array}{c}0.00122^{* * *} * \\
(0.000123)\end{array}$ & $\begin{array}{c}0.00169 * * * \\
(9.20 \mathrm{e}-05)\end{array}$ \\
\hline Observations & 220 & 429 & 1,461 & 715 \\
\hline R-squared & 0.579 & 0.277 & 0.571 & 0.745 \\
\hline
\end{tabular}


Table A.10A. Non-Bank Dependence and Aggregate Car Sales, Additional

\section{Robustness Tests}

The dependent variable is the log change in total car sales in 2009 relative to 2008 . All columns include the same set of controls as in column 2 of Table IV. Column 1 includes the unemployment rate and median leverage in the county; Column 2 includes the change in house prices; column 3 includes household net worth; column 4 includes the change in the demographic variables; column 5 includes the unemployment rate, while column 6 includes leverage; column 7 interacts leverage with the change in house prices. All regressions are weighted by the county population and include state fixed effects. Standard errors are clustered at the state level. $* * *, * *, *$ denotes significance at the $1 \%, 5 \%$, and $10 \%$ levels.

\begin{tabular}{|c|c|c|c|c|c|c|c|}
\hline VARIABLES & $\begin{array}{c}(1) \\
\text { Unemployment } \\
\text { and leverage }\end{array}$ & $\begin{array}{c}\text { (2) } \\
\text { House prices } \\
\end{array}$ & $\begin{array}{c}\text { (3) } \\
\text { Household net worth } \\
\end{array}$ & $\begin{array}{c}(4) \\
\text { Changes } \\
\end{array}$ & $\begin{array}{c}\text { (5) } \\
\text { Unemployment }\end{array}$ & $\begin{array}{c}\text { (6) } \\
\text { Leverage } \\
\end{array}$ & $\begin{array}{c}(7) \\
\text { Leverage*house } \\
\text { price change }\end{array}$ \\
\hline $\begin{array}{l}\text { Non-bank } \\
\text { dependence, } 200 \\
\text { (Polk), financed } \\
\text { transactions }\end{array}$ & $\begin{array}{l}-0.0881 \\
(0.0549)\end{array}$ & $\begin{array}{l}-0.0761 \\
(0.0743)\end{array}$ & $\begin{array}{l}-0.0583 \\
(0.0730)\end{array}$ & $\begin{array}{l}-0.0822 * \\
(0.0415)\end{array}$ & $\begin{array}{l}-0.0930 * \\
(0.0492)\end{array}$ & $\begin{array}{l}-0.0875 \\
(0.0548)\end{array}$ & $\begin{array}{l}-0.0724 \\
(0.0737)\end{array}$ \\
\hline Observations & 2,056 & 958 & 932 & 2,824 & 2,825 & 2,056 & 958 \\
\hline R-squared & 0.728 & 0.796 & 0.791 & 0.690 & 0.703 & 0.728 & 0.796 \\
\hline
\end{tabular}

\section{Table A.10B. Non-Bank Dependence and Aggregate Car Sales, Additional Robustness Tests: Unweighted Regressions}

The dependent variable is the log change in total car sales in 2009 relative to 2008 . All columns include the same set of controls as in column (2) of Table IV. Column (1) includes the unemployment rate and median leverage in the county; column (2) includes the change in house prices; column (3) includes household net worth; column (4) includes the change in the demographic variables; column (5) includes the unemployment rate, while column (6) includes leverage; column (7) interacts leverage with the change in house prices. All regressions include state fixed effects. Standard errors are clustered at the state level. ***, $* *, *$ denotes significance at the $1 \%, 5 \%$, and $10 \%$ levels.

\begin{tabular}{|c|c|c|c|c|c|c|c|}
\hline VARIABLES & $\begin{array}{c}(1) \\
\text { Unemployment } \\
\text { and leverage }\end{array}$ & $\begin{array}{c}\text { (2) } \\
\text { House prices }\end{array}$ & $\begin{array}{c}\text { (3) } \\
\text { Household net worth }\end{array}$ & $\begin{array}{c}\text { (4) } \\
\text { Changes }\end{array}$ & $\begin{array}{c}\text { (5) } \\
\text { Unemployment }\end{array}$ & $\begin{array}{c}\text { (6) } \\
\text { Leverage }\end{array}$ & $\begin{array}{c}(7) \\
\text { Leverage*house } \\
\text { price change }\end{array}$ \\
\hline $\begin{array}{l}\text { Non-bank } \\
\text { dependence, } 2008 \\
\text { (Polk), financed } \\
\text { transactions }\end{array}$ & $\begin{array}{c}-0.0844 * * * \\
(0.0312)\end{array}$ & $\begin{array}{l}-0.102 * * \\
(0.0493)\end{array}$ & $\begin{array}{l}-0.106^{* * *} \\
(0.0501)\end{array}$ & $\begin{array}{c}-0.0677 * * \\
(0.0325)\end{array}$ & $\begin{array}{c}-0.0884 * * * \\
(0.0325)\end{array}$ & $\begin{array}{c}-0.0844 * * * \\
(0.0311)\end{array}$ & $\begin{array}{l}-0.0992 * \\
(0.0495)\end{array}$ \\
\hline Observations & 2,056 & 958 & 932 & 2,824 & 2,825 & 2,056 & 958 \\
\hline R-squared & 0.728 & 0.796 & 0.791 & 0.690 & 0.703 & 0.728 & 0.796 \\
\hline
\end{tabular}

\section{Table A.10C. Non-Bank Dependence and Aggregate Car Sales, Additional Robustness Tests: Equifax Measure of Non-Bank Dependence}

The dependent variable is the log change in total car sales in 2009 relative to 2008. All columns include the same set of controls as in column (2) of Table IV. Column (1) includes the unemployment rate and median leverage in the county; column (2) includes the change in house prices; column (3) includes household net worth; column (4) includes the change in the demographic variables; column (5) includes the unemployment rate, while column (6) includes leverage; column (7) interacts leverage with the change in 
house prices. All regressions are weighted by the county population and include state fixed effects. Standard errors are clustered at the state level. $* * *, * *, *$ denotes significance at the $1 \%, 5 \%$, and $10 \%$ levels.

\begin{tabular}{|c|c|c|c|c|c|c|c|}
\hline VARIABLES & $\begin{array}{c}\text { (1) } \\
\text { Unemployment } \\
\text { and leverage }\end{array}$ & $\begin{array}{c}\text { (2) } \\
\text { House prices } \\
\end{array}$ & $\begin{array}{c}\text { (3) } \\
\text { Household net worth }\end{array}$ & $\begin{array}{c}\text { (4) } \\
\text { Changes } \\
\end{array}$ & $\begin{array}{c}\text { (5) } \\
\text { Unemployment } \\
\end{array}$ & $\begin{array}{c}\text { (6) } \\
\text { Leverage } \\
\end{array}$ & $\begin{array}{c}(7) \\
\text { Leverage*house } \\
\text { price change } \\
\end{array}$ \\
\hline $\begin{array}{l}\text { Non-bank } \\
\text { dependence, } 2006 \\
\text { (Equifax), financed } \\
\text { transactions }\end{array}$ & $\begin{array}{c}-0.132 * * * \\
(0.0296)\end{array}$ & $\begin{array}{c}-0.120 * * * \\
(0.0375)\end{array}$ & $\begin{array}{c}-0.117 * * * \\
(0.0394)\end{array}$ & $\begin{array}{c}-0.0984 * * * \\
(0.0209)\end{array}$ & $\begin{array}{c}-0.117 * * * \\
(0.0250)\end{array}$ & $\begin{array}{c}-0.131 * * * \\
(0.0298)\end{array}$ & $\begin{array}{c}-0.121 * * * \\
(0.0375)\end{array}$ \\
\hline Observations & 2,056 & 958 & 932 & 2,824 & 2,825 & 2,056 & 958 \\
\hline R-squared & 0.728 & 0.796 & 0.791 & 0.690 & 0.703 & 0.728 & 0.796 \\
\hline
\end{tabular}




\section{Table A.11A. Non-Bank Dependence and Car Buying, Individual-Level Evidence, Additional Robustness Checks, Part I}

This table considers additional robustness checks for the results presented in Table 7 of the main text. The dependent variable in column 1 is the probability that an individual obtains non-bank automotive creditthe sample period is 2007. In column 2 the dependent variable is the probability of obtaining mortgage credit, 2007-2009. In column 3, the dependent variable equals 1 if the credit limit is positive and 0 otherwise. In column 3, the dependent variable, the utilization rate, equals the ratio of credit balances to credit limit.

\begin{tabular}{|c|c|c|c|c|}
\hline & $(1)$ & (2) & (3) & (4) \\
\hline & Non-banks & Mortgage credit & Credit limit dummy & Utilization rate \\
\hline VARIABLES & 2007 & $2007-2009$ & $2008-2009$ & $2008-2009$ \\
\hline \multirow[t]{2}{*}{ FICO score, $\log$} & $-0.0249^{* * *}$ & $0.396 * * *$ & $0.536 * * *$ & $-0.0175 * * *$ \\
\hline & $(0.00125)$ & $(0.0154)$ & $(0.0257)$ & $(0.00140)$ \\
\hline \multirow[t]{2}{*}{ Credit card balance, $\log$} & $-0.000406 * * *$ & $0.00339 * * *$ & $0.108^{* * * *}$ & $0.0932 * * *$ \\
\hline & $(4.36 \mathrm{e}-05)$ & $(0.00118)$ & $(0.000697)$ & $(0.000925)$ \\
\hline \multirow[t]{2}{*}{ Credit card limit, log } & $0.000392^{* * *}$ & $0.0276^{* * *}$ & --- & --- \\
\hline & $(1.99 \mathrm{e}-05)$ & $(0.000675)$ & --- & --- \\
\hline \multirow[t]{2}{*}{ Age } & $0.198 * * *$ & $4.048 * * *$ & $-4.797 * * *$ & $0.290 * * *$ \\
\hline & $(0.0141)$ & $(0.368)$ & $(0.180)$ & $(0.0280)$ \\
\hline \multirow[t]{2}{*}{ Non-bank dependence (Polk) } & $0.00605^{* *}$ & 0.00240 & $-0.173 * * *$ & -0.000588 \\
\hline & $(0.00241)$ & $(0.0272)$ & $(0.0196)$ & $(0.00119)$ \\
\hline \multirow[t]{2}{*}{ Non-bank dependence (Polk)* 2007 Q2 } & $2.97 \mathrm{e}-05$ & $-0.00815^{* *}$ & --- & --- \\
\hline & $(0.000765)$ & $(0.00383)$ & --- & --- \\
\hline \multirow{2}{*}{ Non-bank dependence (Polk)* 2007 Q3 } & 0.00130 & $-0.0119 * * *$ & --- & --- \\
\hline & $(0.00261)$ & $(0.00293)$ & $\begin{array}{l}-- \\
\end{array}$ & --- \\
\hline \multirow{2}{*}{ Non-bank dependence (Polk)* 2007 Q4 } & -0.00144 & $-0.0114 * * *$ & --- & --- \\
\hline & $(0.00221)$ & $(0.00373)$ & --- & --- \\
\hline \multirow{2}{*}{ Non-bank dependence (Polk)* 2008 Q1 } & --- & $-0.0115^{* *}$ & --- & --- \\
\hline & --- & $(0.00521)$ & --- & --- \\
\hline \multirow[t]{2}{*}{ Non-bank dependence (Polk)* 2008 Q2 } & --- & $-0.0126^{*}$ & $-0.00934 * * *$ & 0.000345 \\
\hline & --- & $(0.00660)$ & $(0.00201)$ & $(0.000493)$ \\
\hline \multirow[t]{2}{*}{ Non-bank dependence (Polk)* 2008 Q3 } & --- & $-0.0142 * *$ & -0.00176 & 0.000855 \\
\hline & --- & $(0.00611)$ & $(0.00426)$ & $(0.000712)$ \\
\hline \multirow[t]{2}{*}{ Non-bank dependence (Polk)*2008 Q4 } & --- & $-0.0121 * *$ & 0.00539 & $-4.38 \mathrm{e}-05$ \\
\hline & --- & $(0.00489)$ & $(0.00673)$ & $(0.000847)$ \\
\hline \multirow[t]{2}{*}{ Non-bank dependence (Polk)* 2009 Q1 } & --- & $-0.00947 * *$ & $0.0242 * *$ & -0.000407 \\
\hline & --- & $(0.00424)$ & $(0.00903)$ & $(0.000984)$ \\
\hline \multirow[t]{2}{*}{ Non-bank dependence (Polk)* 2009 Q2 } & --- & $-0.0104^{*}$ & $0.0259 * *$ & 0.000344 \\
\hline & --- & $(0.00532)$ & $(0.00983)$ & $(0.000917)$ \\
\hline \multirow[t]{2}{*}{ Non-bank dependence (Polk)* 2009 Q3 } & --- & $-0.0116^{* *}$ & $0.0241 * *$ & $3.50 \mathrm{e}-06$ \\
\hline & --- & $(0.00506)$ & $(0.0106)$ & $(0.00138)$ \\
\hline \multirow[t]{2}{*}{ Non-bank dependence (Polk)*2009 Q4 } & --- & $-0.0129 * *$ & $0.0239 * *$ & 0.000181 \\
\hline & --- & $(0.00484)$ & $(0.00984)$ & $(0.00120)$ \\
\hline Observations & $11,896,155$ & $35,561,957$ & $23,665,802$ & $5,014,678$ \\
\hline R-squared & 0.004 & 0.113 & 0.193 & 0.841 \\
\hline
\end{tabular}




\section{Table A.11B. Non-Bank Dependence and Car Buying, Individual-Level Evidence, Additional Robustness Checks, Part II}

This table considers additional robustness checks for the results presented in Table 7 of the main text. The analysis is at the county level. In column 1, the dependent variable is the log change in mortgage balances inside the county; column 2: the change in credit card balances. Columns 3 and 4 respecitively use the total log mortgage and credit balances inside the county, in 2009.

\begin{tabular}{|c|c|c|c|c|}
\hline VARIABLES & $\begin{array}{c}(1) \\
\text { Total mortgage balance } \\
\text { change, 2009-2008 }\end{array}$ & $\begin{array}{c}(2) \\
\text { Total credit card balance } \\
\text { change, } 2009-2008\end{array}$ & $\begin{array}{c}(3) \\
\text { Total mortgage balance, log } \\
2009 \\
\end{array}$ & $\begin{array}{l}(4) \\
\text { Total credit card balance, log } \\
2009 \\
\end{array}$ \\
\hline $\begin{array}{l}\text { Non-bank dependence, } 2008 \text { Q1 (Polk), } \\
\text { financed transactions }\end{array}$ & $\begin{array}{l}-0.00807 \\
(0.0263)\end{array}$ & $\begin{array}{c}0.205 \\
(0.295)\end{array}$ & $\begin{array}{r}-0.0992 \\
(0.159)\end{array}$ & $\begin{array}{l}-0.205 \\
(0.547)\end{array}$ \\
\hline County area, log & $\begin{array}{l}-0.000541 \\
(0.00185)\end{array}$ & $\begin{array}{l}-0.0285 \\
(0.0244)\end{array}$ & $\begin{array}{c}-0.0378^{* * *} \\
(0.0118)\end{array}$ & $\begin{array}{c}-0.0864 * * * \\
(0.0264)\end{array}$ \\
\hline Population, log & $\begin{array}{l}0.0271 * * \\
(0.0125)\end{array}$ & $\begin{array}{l}0.0477 \\
(0.158)\end{array}$ & $\begin{array}{l}0.791 * * * \\
(0.0909)\end{array}$ & $\begin{array}{c}0.273 \\
(0.273)\end{array}$ \\
\hline Median income, log & $\begin{array}{l}-0.0155 \\
(0.0122)\end{array}$ & $\begin{array}{c}0.528 * * * \\
(0.144)\end{array}$ & $\begin{array}{l}1.734 * * * \\
(0.0676)\end{array}$ & $\begin{array}{c}1.046 * * * \\
(0.197)\end{array}$ \\
\hline African American population, $\log$ & $\begin{array}{l}-0.00257 \\
(0.00221)\end{array}$ & $\begin{array}{c}-0.0869 * * \\
(0.0343)\end{array}$ & $\begin{array}{l}-0.0277^{*} \\
(0.0154)\end{array}$ & $\begin{array}{l}-0.105 * * \\
(0.0444)\end{array}$ \\
\hline White population, $\log$ & $\begin{array}{c}-0.0237 * * \\
(0.0110)\end{array}$ & $\begin{array}{c}0.138 \\
(0.142)\end{array}$ & $\begin{array}{l}0.329 * * * \\
(0.0875)\end{array}$ & $\begin{array}{c}1.244 * * * \\
(0.246)\end{array}$ \\
\hline Gini coefficient & $\begin{array}{c}-0.142 * * * \\
(0.0496)\end{array}$ & $\begin{array}{c}1.344 \\
(0.834)\end{array}$ & $\begin{array}{c}1.363 * * * \\
(0.328)\end{array}$ & $\begin{array}{c}-2.536 * * * \\
(0.806)\end{array}$ \\
\hline Employment in automobile, share & $\begin{array}{r}0.00481 \\
(0.127)\end{array}$ & $\begin{array}{c}0.964 \\
(1.596)\end{array}$ & $\begin{array}{l}0.0513 \\
(0.568)\end{array}$ & $\begin{array}{c}0.992 \\
(1.734)\end{array}$ \\
\hline Median credit score, 2008 Q1 (Trans Union) & $\begin{array}{c}9.09 \mathrm{e}-05 \\
(9.04 \mathrm{e}-05)\end{array}$ & $\begin{array}{l}-0.000844 \\
(0.000937)\end{array}$ & $\begin{array}{l}0.000719 * \\
(0.000408)\end{array}$ & $\begin{array}{c}-0.00456^{* * *} \\
(0.00163)\end{array}$ \\
\hline $\begin{array}{l}\text { Observations } \\
\text { R-squared }\end{array}$ & $\begin{array}{l}2,824 \\
0.029\end{array}$ & $\begin{array}{l}2,824 \\
0.070\end{array}$ & $\begin{array}{l}2,824 \\
0.983\end{array}$ & $\begin{array}{l}2,824 \\
0.781\end{array}$ \\
\hline
\end{tabular}




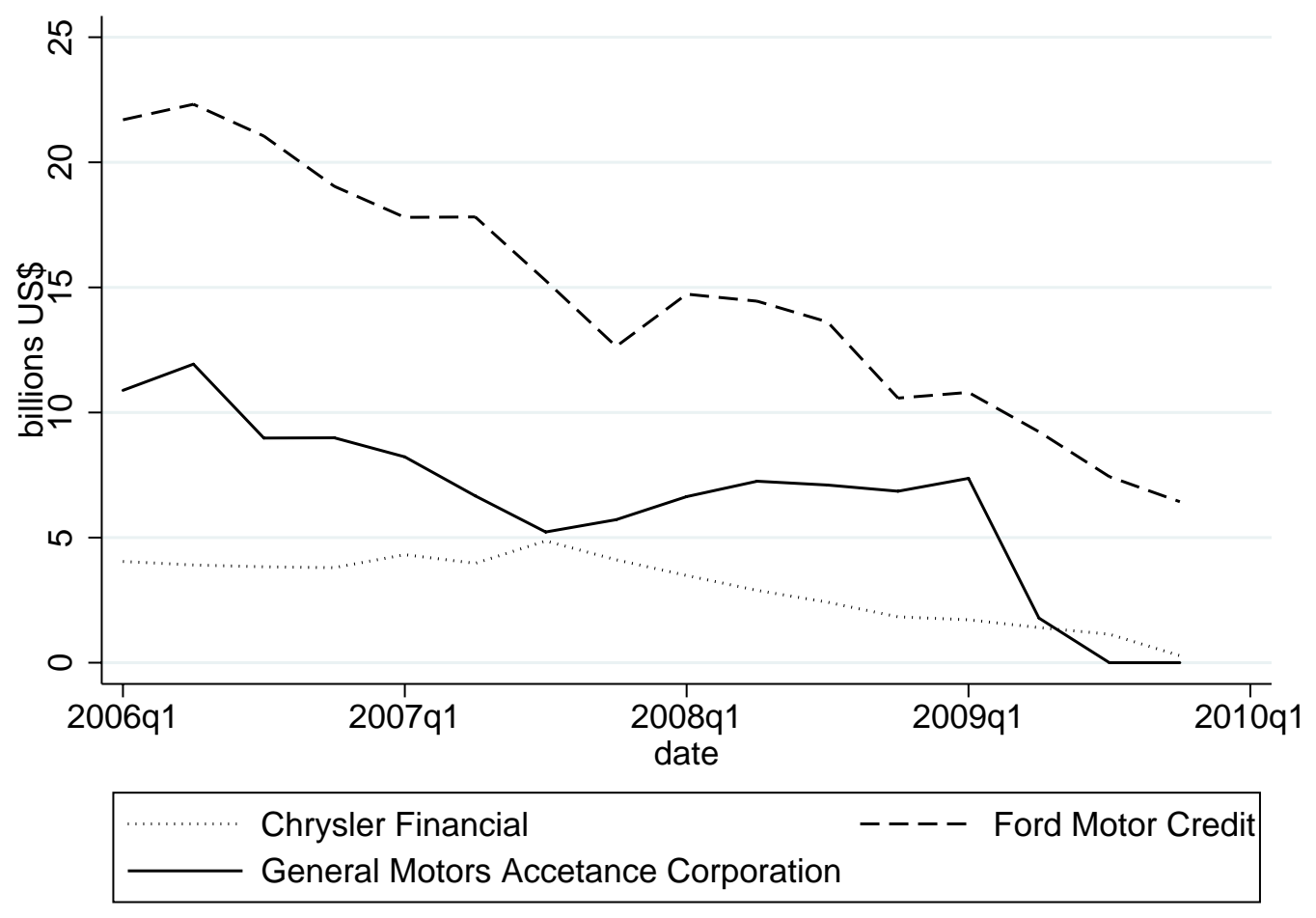

Figure A.1. Outstanding Issuances of Asset-Backed Commercial Paper. Outstanding stock asset-backed commercial paper issued by three captive finance companies, 2006 Q1-2009 Q4. Source: Moody's Investor Services. 


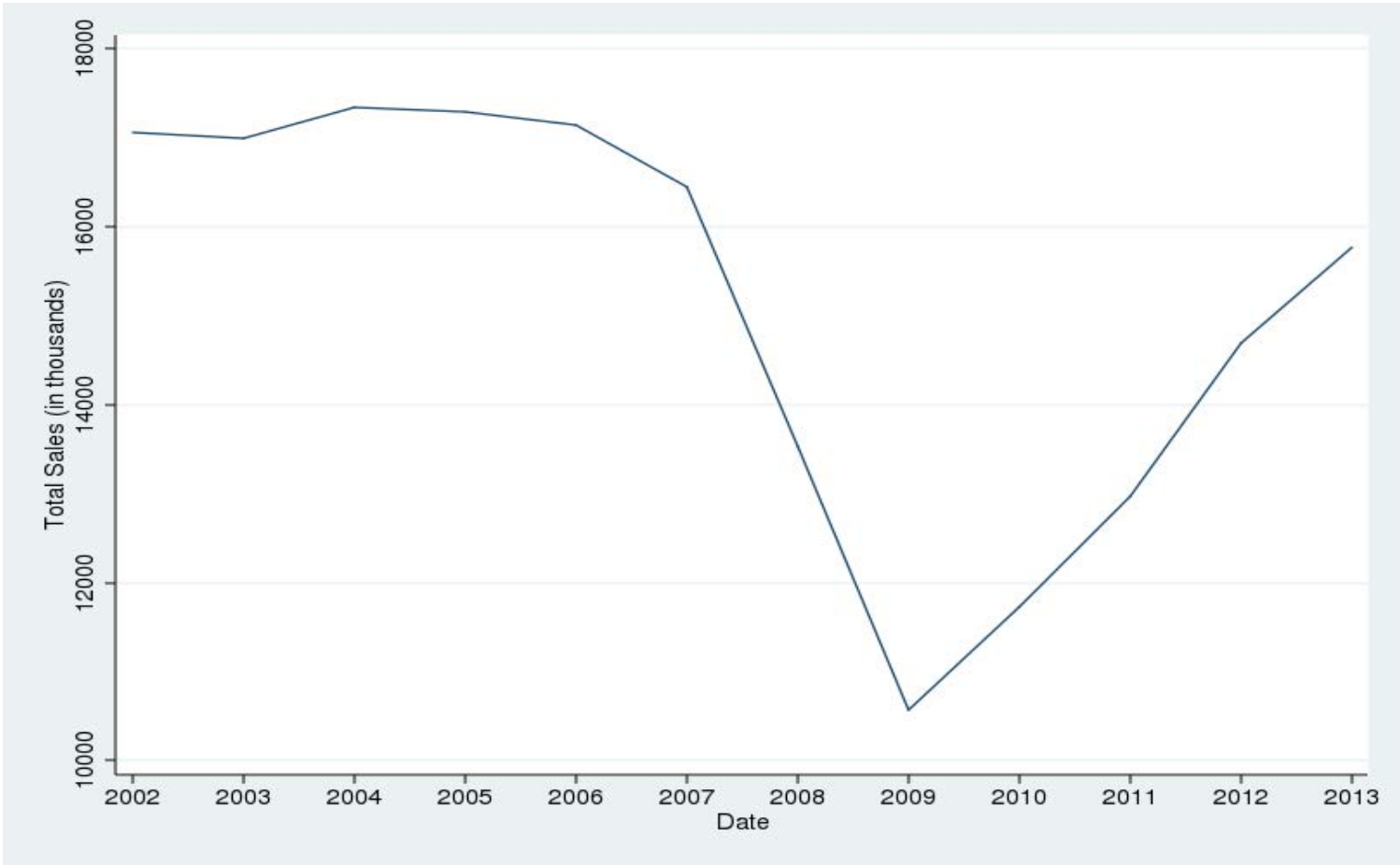

Figure A.2. Total Car Sales, 2002-2013. Total annual car purchases in Polk. 


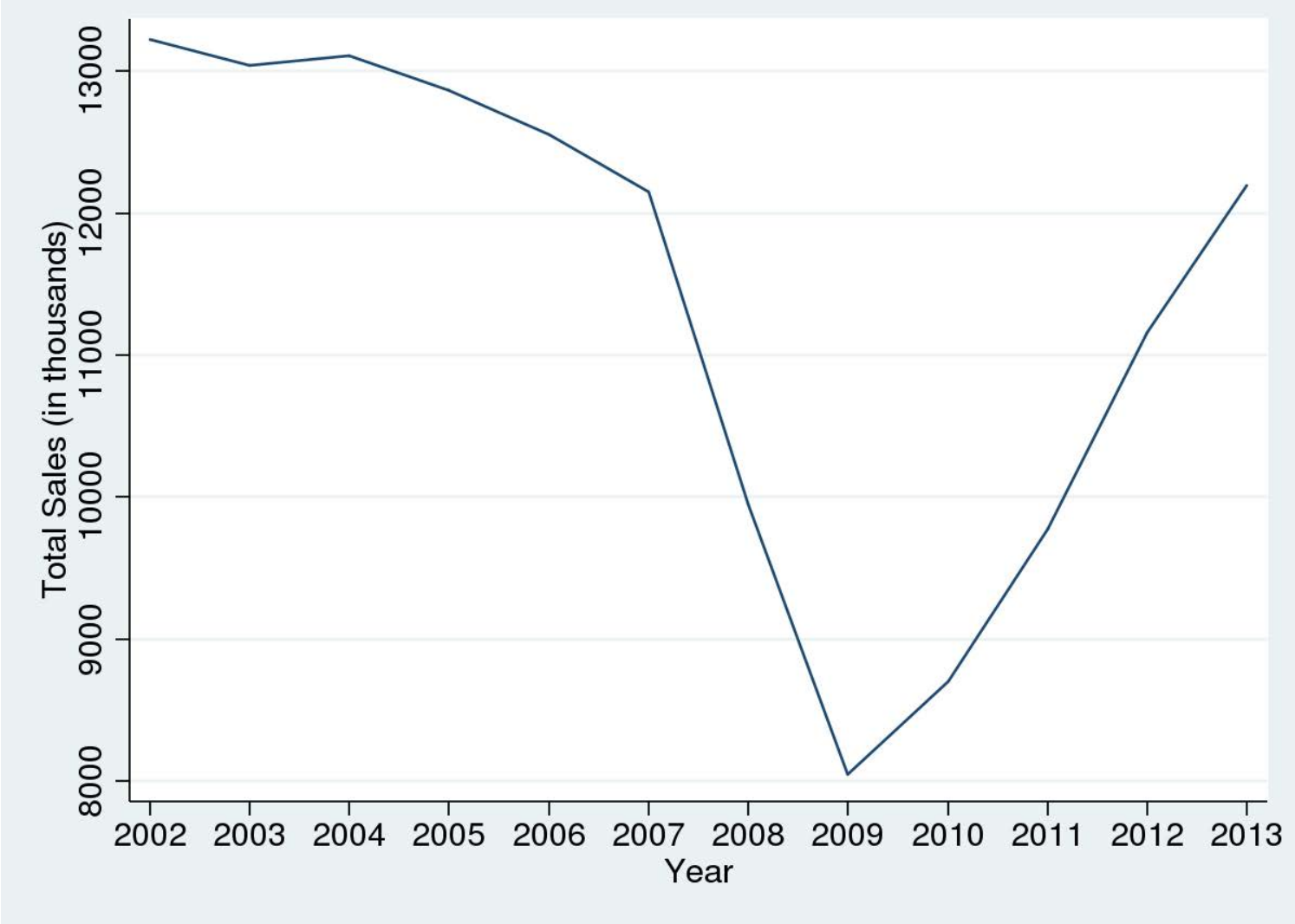

Figure A.3. Total Retail Car Sales, 2002-2013. Retail car sales are the sum of retail leases and retail purchases in Polk. 


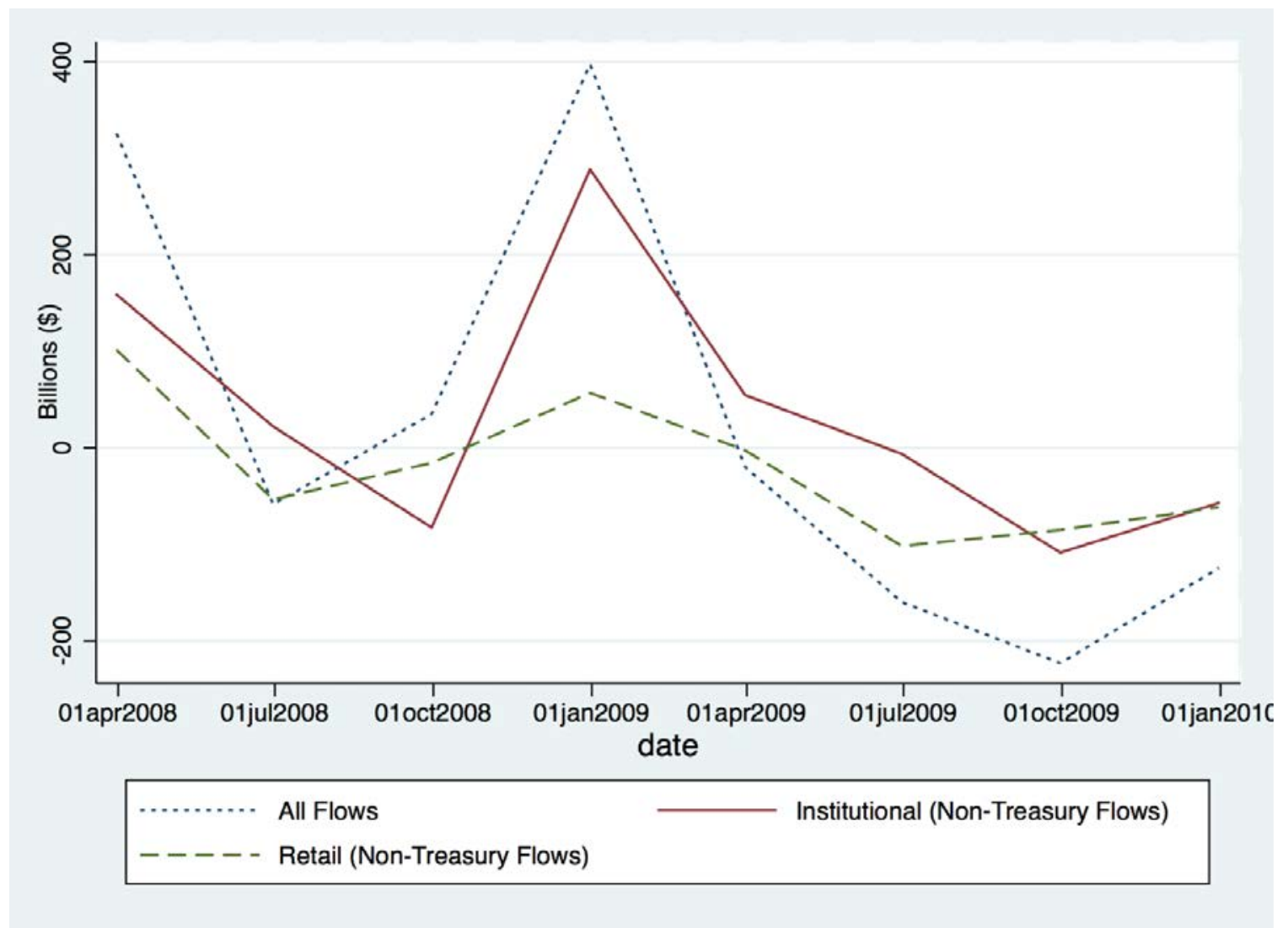

Figure A.4. Quarterly Net Flows to Money Market Funds, 2008-2009. Flows are calculated using data from Flow of Funds. 